\title{
Notes
}

\section{The Rushdie Incident as}

\section{Law-and-Literature Parable}

\author{
Pinaki Chakravorty
}

Given relatively unsophisticated notions of "law" and "literature," Salman Rushdie's incendiary novel, The Satanic Verses,' is "literature," and the measures taken or attempted against it in Iran, India, and elsewhere, ${ }^{2}$ however questionable, are "law" or interpretations of law. That there is interaction and clash between "law" and "literature" in the Rushdie incident is therefore obvious as a matter of common sense. That the Rushdie incident might have parabolic significance in the context of existing law-and-literature scholarship ${ }^{3}$ is also, therefore, commonsensically valid. A parable is a story at once particular and universal ${ }^{4}-a$ fact-intensive, narrative example (and possibly even subversive counterexample ${ }^{5}$ ) that moves beyond its particular facts to general maxims. By retelling the Rushdie incident within a law-and-literature

1. Salman Rushdie, The Satanic Verses (1989).

2. For a description of The Satanic Verses and the reactions it evoked, see infra pan 1 .

3. For a survey of law-and-literature scholarship that continues to be useful despite its age, see Robert Weisberg, The Law-Literature Enterprise, 1 YALE J.L. \& HUMAN. 1 (1988).

4. See MARY ANN TOLBERT, PERSPectives on the PARABles: AN APProACH to MULTIPLE INTERPRETATIONS 35-40 (1979) (observing that structural logic of parable abstracts ordinary meaning of story to more universal meaning, endowing particular instance with general explanatory capability). I am indebted to Professor Robert Ferguson for directing my attention to the structural aspects of religious parables. Letter from Robert Ferguson. Professor. Columbia University School of Law, to author (June 1. 1994) (on file with author).

5. See, e.g., William Herzog II, Parables as Subversive Speech: Jesus as Pedagogue of the OPPRESSED (1994) (arguing that Jesus' parables were about real conditions of exploitation in Palestine): see also Richard Delgado, Storytelling for Oppositionists and Others: A Plea for Narratve, 87 MiCH. L REV. 2411, 2413 (1989) ("Stories, parables, chronicles, and narratives are powerful means for destroying mindset . . ."). 
context, ${ }^{6} \mathrm{I}$ will thus be telling a story about law and literature, in the tradition of legal storytelling begun by the law-and-literature movement itself. ${ }^{7} \mathrm{My}$ story, in turn, will demonstrate how capacities for reading and telling stories can be similar, and yet very different, within law and literature.

This Note presents the media incident surrounding Rushdie's publication of The Satanic Verses as a parable for the coexisting proximity and distance between literature and law. Part I factually situates the parable by summarizing the legal action within the incident and the novel that instigated it. Part II suggests that the Rushdie incident speaks authoritatively about law and literature because it can itself be understood as a complex literary narrative constrained by its own uncomfortably trial-like, bipolar medium.

Having established a parabolic strategy of reading, this Note goes on to read the Rushdie incident for its lessons about the law-literature boundary. First (as discussed in Part III), the incident demonstrates that legal pronouncement, when based on the reading of a literary narrative, may do violence and injustice to literary meaning. The editing and reordering of evidence necessary to achieve any legal pronouncement means, when the "evidence" is literary, that reading in the literary sense must be compromised or authoritatively simplified into trial-like side taking. Second (as discussed in Part IV), the Rushdie incident implicates an author who had previously aspired to make his fiction a quasi-legal instrument of political and social change, but who, upon success, insists that politically opinionated fiction should not be the same as politically motivated action for purposes of legal condemnation. The visible material effects of The Satanic Verses make Rushdie's assertion of literature's quasi-legal power believable; yet equally believable are his later caveats about fiction's limitations as lawmaker. Finally, the incident pinpoints a further discrepancy between law and literature (discussed in Part V) by underscoring the different conceptions of authorial intention assumed by a "multivoiced" literary novel and by the "univocal" legal society that condemns it. It nonetheless remains difficult to draw a lesson of law-literature discrepancy from the Rushdie incident, since "pluralist" championing of novelistic multivoicedness within a multicultural state appears to reconcile law and literature, albeit with some limitations. Furthermore, "fundamentalist"

6. The Spring 1990 issue of The Cardozo Studies in Law and Literature prefaced its reprinting of several writers' and artists' responses to the fatwa by declaring:

For students of Law and Literature, the essays, articles, speeches, protests and calls for action over [The Satanic Verses] are immensely instructive. They provide an encyclopedic review of the power of literature within a society and the way in which legal systems establish or limit the zone in which literature can function.

The Power of Images: Reflections on Salman Rushdie, 2 CARDOZO STUD. L. \& LITERATURE 67, 68 (1990). For a definition and description of the fatwa, see infra part I.A.

The individual responses reprinted in The Cardozo Studies in Law and Literature issue werc taken from a compilation of public reactions to and media coverage of the Rushdie incident. See THB RUSHDIB FILE (Lisa Appignanesi \& Sara Maitland eds., 1990).

7. See infra note 96 and accompanying text. 
censure of Rushdie's novel can be understood in its own terms as a differing literary sensibility.

The Rushdie incident thus argues both for and against the law-literature relationship, its categorical stationings of law and literature being indistinct, nuanced, erratically convergent and divergent. At once example and troublesome counterexample, the incident comes to stand for a certain paradox, factually retold, at the heart of law-and-literature scholarship. Whether it relates to such scholarship in a paradigmatic or parasitic fashion is therefore predictably undecidable.

\section{I. "DIE HE OR JUSTICE MUST": ${ }^{8}$ A BRIEF PARSING OF THE RUSHDIE INCIDENT}

\section{A. Legal Responses to The Satanic Verses}

When Rushdie wrote The Satanic Verses, he was not a stranger to the "business end" of his frequently offended readership. His dangerous roman $a$ clef career, beginning with Midnight's Children, had already earned him a lawsuit in the High Court of London from then Prime Minister of India Indira Gandhi, for one of that book's many thinly veiled and insulting references to Gandhi and her family. ${ }^{9}$ Rushdie's next book (Shame), flippantly fictionalizing more than one generation of Pakistani politicians, had angered those among them who were still alive. ${ }^{10}$ When The Satanic Verses was published in September 1988, Rushdie "expected that the mullahs wouldn't like it.""I

The profusion of legal activity against the book in the few months after its publication was nevertheless surprising. General protest without the color of law ubiquitously legitimated legal interposition, if not the exact legal action taken. ${ }^{12}$ On October 5, 1988, the Indian Finance Ministry announced a ban on the novel, adding that the ban did not detract from the novel's literary and artistic merit. ${ }^{13}$ Other countries, including Bangladesh, Pakistan, South Africa,

8. JOHN MILTON, PARADISE LOST bk. 3, 1. 210 (1674), reprinjed in THE POENIS OF JOHN MILTON 457. 573 (John Carey \& Alastair Fowler eds., 1968).

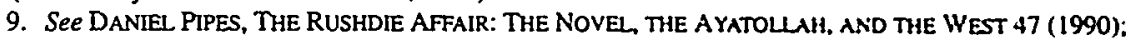
W.J. WEATHERBY, SALMAN RUSHDIE: SENTENCED TO DEATH S0-5I (1990).

10. See PIPES, supra note 9, at 47-48.

11. Bandung File: Interview with Salman Rushdie (Channel 4 (London) television broadcast. Feb. 14, 1989), in THE RUSHDIE FILE, supra note 6, at 21. The term mullah refers to a Muslim clerical and legal authority.

12. Many Muslims offended by The Satanic Verses were nevertheless opposed to Khomeini's fama. See, e.g., Dr. Ali A. Mazrui, The Moral Dilemma of Salman Rushdic's Satanic Verses, Lecture Delivered at Comell University (Mar. 1, 1989), in THE RUShDIE FILE, supra note 6, at 202, 210 ("But the Ayatollah is still wrong in the death sentence."); Harvey Morris el al., Khomeunt Orders Rushdie's Murder. INDEPENDENT (London), Feb. 15, 1989, at 1 ("'We very much regret and denounce Khomeini's statement." (quoting Hesham El-Essawi of Islamic Society for the Promotion of Religious Tolerance in the U.K.)).

13. See Carmel Bedford, Foreword to Fiction, Fact and the Fatwa, in THE RUSHDIE LeTtERS: FREEDOM TO SPEAK, FREEDOM TO WRTTE 127 (Steve MacDonogh \& Article 19 eds., 1993) (hereinafter THE RUSHDIE LETTERS]; see also Salman Rushdie, An Open Letier to the Indian Prime Minister (Oct. 7. 
Sri Lanka, and Sudan followed the Indian government by instituting their own bans. ${ }^{14}$ In December, the Islamic Defence Council in London held a protest rally, and on January 14, 1989, Muslims in Bradford, Yorkshire, burned a copy of The Satanic Verses in public. ${ }^{15}$ On February 12, 1989, approximately 2000 protesters stormed the U.S. Embassy in Islamabad, attacking police with stones and bricks; five protesters were killed when police opened fire on them. ${ }^{16}$

On February 14, 1989, Ayatollah Ruhollah Khomeini of Iran pronounced a fatwa (religious sentence) ${ }^{17}$ on Teheran radio, sentencing to death Rushdie and all involved in the publication of his book "who were aware of its content," and promising heaven and martyrdom to all who would die in implementing the sentence. ${ }^{18}$ The text of the fatwa, though clearly expressing a sentence against blasphemy or apostasy, ${ }^{19}$ is noticeably unspecific about exactly how the book breaches law and therefore gets some of its legal force contextually, from the months of more specific public protest preceding it.

As a legal pronouncement against literature, the fatwa must have begun in some kind of "reading" or "interpretation" of literature, but hermeneutic faculties are subordinated in the final pronouncement to judgment. Despite its religious veneer and its arguably questionable interpretation of Islamic law, ${ }^{20}$ it is as much a legal proclamation as a religious one. Indeed, the categories of law and religion conflate in Islamic law, as this excerpt from Khomeini's elaborate post-fatwa message of February 23, 1989, shows:

Salutations to those who rushed forward to discover the inner meaning of jurisprudence, and became sentinels to their nation and community ....

1988) [hereinafter Rushdie, An Open Letter], reprinted in THE RUSHDIE FILE, supra note 6, at 34 (responding to novel's banning); Syed Shahabuddin, "You Did This With Satanic Forethought, Mr Rushdie", TIMES OF INDIA, Oct. 13, 1988, reprinted in THE RUSHDIE FILE, supra note 6, at 37, 40 (listing other Indian laws that could have been used against the book).

14. See Bedford, supra note 13, at 128-29; M.M. Slaughter, The Salman Rushdie Affair: Apostasy, Honor, and Freedom of Speech, 79 VA. L. REv. 153, 156 (1993).

15. See Bedford, supra note 13, at 128-29.

16. Id. at 129.

17. For a more precise definition of the term fatwa, see Slaughter, supra note 14, at 175 (defining fatwas as "formal legal opinions in the nature of advisory opinions as to what is lawful under Islamic law").

18. See PIPES, supra note 9, at 27, 87; Carmel Bedford, Fiction, Fact and the Fatwa, in THE RUSHDIB LETTERS, supra note 13, at 130. For reporting of the fatwa in London, see Robin Lustig et al., War of the Word, OBSERVER (London), Feb. 19, 1989, at 19, reprinted in THE RUSHDIE FILE, supra note 6, at 68.

19. It is helpful to remember that blasphemy and treason are nearly indistinguishable in Islamic law. See Ali A. Maznui, "Satanic Verses" or a Satanic Novel?, in THE KIsS OF JUDAS: AfraIRS OF A BROWN SAHIB 61, 62-65 (Munawar A. Anees ed., 1989) [hereinafter THE KISS OF JUDAS].

20. See PIPES, supra note 9, at 87-95; MAlise RUTHVEN, A SATANIC AfFaIR: SAlMan Rushdib AND THE RAGE OF ISLAM 112-13 (1990); Sadik J. Al-Azm, Is the Fatwa a Fatwa?, in FoR RUSHDIE: EsSAYS BY ARAB AND MUSLIM WRTrERS IN DEFENSE OF FREE SPEECH 21 (Kevin Anderson \& Kenneth Whitehead trans., George Braziller 1994) (1993); Ann Elizabeth Mayer, Islam and the State, 12 CARDozo L. RBv. 1015, 1051-52 (1991); Slaughter, supra note 14, at 175-77. But cf. SHABBIR AKHTAR, BE CAREFul wTH MUHAMmad! THE SALMAN RUSHDIE AFFAIR 77-78 (1989) (defending fatwa's legitimate basis in Islamic law). 
For hundreds of years ... [t]he oppressed people have always drunk their fill from the pure fountain of the gnosis of illustrious jurisconsults. ...

... The Satanic Verses is . . a calculated move aimed at rooting out religion and religiousness, aimed above all at Islam and its clergy. ... . [I]f the World Devourers could, they would have burnt out the roots and title of the clergy. ${ }^{21}$

To use Robert Cover's terms, the fatwa, like other measures taken against the novel, summons "imperial" force to create "normative meaning" (specifically, that the book is offensive and cannot be countenanced); in this, it is vitally legal. ${ }^{22}$

Legal activism against The Satanic Verses did not stop with the fanva. British Muslims later sued Rushdie and his publisher in English court under common law charges of blasphemy and sedition. ${ }^{23}$ In the case against Rushdie, the Queen's Bench Division of the High Court affirmed a denial of seditious libel and blasphemous libel charges, on the basis that the common law offense of blasphemuus libel applied only to attacks on the Christian religion. $^{24}$

Perhaps other legal measures could have been marshaled that were not. In a plea to British Prime Minister Margaret Thatcher, Dr. Syed Pasha of the Union of Muslim Organisations in Britain asked (unsuccessfully) for prosecution of Rushdie and his publisher under the British Public Order Act. $^{25}$ In a public letter, Indian Member of Parliament (MP) Syed Shahabuddin threatened Rushdie with several Indian Penal Code provisions that could have been used against him, had Rushdie only been living in India. ${ }^{26}$

21. A Challenge to the World Devourers, GuARDIaN (London), Mar. 6, 1989, at 21 (transcript of Teheran radio address); cf. Ann Elizabeth Mayer, Low and Religion in the Muslim Middle East. 35 AM. J. COMP. L. 127, 157-60 (1987) (outlining Khomeini's Islamic legal theories and their impact on Iranian Constitution). For a discussion of the Islamic law of apostasy. see Sami A. Aldeeb Abu-Sahlieh. Luberte Religieuse et Apostasie dans I'Islam [Religious Freedom and Apostasy in Islam], 3 PRAXIS JURIDIQUE ET RELIGION 43 (1986). For a general survey of Islamic law, see JOSEPH SCHACIT, AN INTRODLCTION TO ISLAMIC LAW (1964).

22. See Robert M. Cover, The Supreme Coun, 1982 Term-Foreword: Nomos and Narranve, 97 HARV. L. REV. 4, 12-13 (1983).

23. See The Satanic Verses in the High Court, NEw HuMasist, May 1990, al 12, 12-13; Slaughter. supra note 14 , at 158,184 n.173.

24. See Anne Bayefsky \& Joan Fitzpatrick, Intemasional Human Rights Low in United States Courts: A Comparative Perspective, 14 MICH. J. INT'L L. 1, 58-59 (1992) (discussing dispostition of The Queen v. Chief Magistrate, ex parte Choudhury, [1991] I All E.R. 306 (Q.B. 1990)). The court refused to enterain suggestions that such construction of the common law would discriminate on the basis of religion in violation of Articles 9 and 14 of the European Convention for the Protection of Human Rights and Fundamental Freedoms. Id. For the relevant text of these articles, see Convention for the Protection of Human Rights and Fundamental Freedoms, Nov. 4, 1950, arts. 9, 14, 213 U.N.T.S. 221. $230-33$.

25. Amit Roy \& Deirdre Fernand, SUNDAY TIMES (London), Feb. 19, 1989, at A15, Al6. For relevant text of the British Public Order Act, see Slaughter, supre note 14, at 158 n.22.

26. See Shahabuddin, supra note 13, at 40. For counterresponses to the legal reaction against The Satanic Verses, see William Vogeler, What Are Legal Ramifications of Rushdie Furar?. L.A. DAllY J., Mar. 10, 1989, at 1. 
However overbearing and authoritarian, all legal response against The Satanic Verses actually relates to the literary text as both master and slave. Judgment is subservient to the extent that it must ground itself in the novel, though judgmental "reading," even in good faith, characteristically crosses into forcible misreading.

\section{B. The Novel and How It Offends}

The Satanic Verses is a precarious collection of overdetermined stories so uncontainable that they overflow into one another; in uncanny ways they even overflow into and circumscribe the terms of the ensuing incident. The central narrative begins with two men-Gibreel Farishta, dream-tormented schizophrenic ${ }^{27}$ and sometime anxious religionist turned disbeliever, ${ }^{28}$ a larger-than-life cinema idol from the excruciatingly melodramatic "theological" genre of Hindi films; ${ }^{29}$ and Saladin Chamcha, ${ }^{30}$ a British-educated Indian living in England, called the "Man of a Thousand Voices and a Voice" by virtue of his television and radio advertising background, ${ }^{31}$ and therefore, importantly, also an actor. "[A]ctors are not people,"32 muses Chamcha at the beginning of the novel, foreboding Farishta's metamorphosis into an angel and Chamcha's own transformation into fiend, complete with bestial horns and hooves. Bedeviled by his own appearance, Chamcha is taken by the English police for an illegal immigrant, beaten and manhandled, ending up in a hospital with other migrants, themselves transformed into mythical creatures. ${ }^{33}$ The full implications of this devil-angel dichotomy are complex, and Rushdie's prose often requires an intimate familiarity with the innards of subcontinental culture and the rhythms of subcontinental speech. Nevertheless, Chamcha is being "punished" for his migrant status, for his betrayal of the authenticity and traditionalism essential to a false sense of continuity with the past, whereas .Farishta is being rewarded for his ineptly formulaic embrace of this same rootedness. ${ }^{34}$

27. RUSHDIE, THE SATANIC VERSES, supra note 1, at 83; see also SALMAN RUSHDIE, In Good Faill, in IMAGINARY HOMELANDS 393, 398 (1991) ("His greatest torments . . . [are] in the form of dreams.").

28. See RUSHDIE, THE SATANIC VERSES, supra note 1, at 21-22 ("He grew up believing in God, angels, demons, afreets, djinns, as matter-of-factly as if they were bullock-carts or lamp-posts . . . . Sometimes, though, he caught himself in the act of forming blasphemous thoughts . . ."); id. at 29 ("[I]t became clear that he had ... lost his faith.").

29. See id. at 24-29.

30. The name is shortened from "Salahuddin" to thyme with "Aladdin," whose story reverberates through Saladin's in significant ways.

31. RUSHDIE, THE SATANIC VERSES, supra note 1, at 60-63.

32. Id. at 34 ("[L]es acteurs ne sont pas des gens.").

33. Id. at $141-42,157-62,167-71$.

34. See id. at 426-27. Immediately after admitting to this intention, the narrator undercuts it. Id. at 427 ("[T]his sounds, does it not, dangerously like an intentionalist fallacy?"). In fact, very few conclusions can be reached about the book that the book itself has not already anticipated and complicated. The interpreter handling the bait can never be sure whether she is fish or fisherman. If the Chamcha-Farishta story werc reducible to punishment and reward, it would essentially be a tragedy on migration and colonialism. But it is not so reducible. Rushdie himself commented that the writing of The Satanic Verses thwarted any ideas 
Notwithstanding the profanity that is scattered throughout the book and often directed at figures sacred to Islam (e.g., "bastard" for Abraham and "fucking clowns" for the Companions of the Prophet ${ }^{35}$ ), the other narratives account for most of the offense taken. ${ }^{36}$ The story of "Mahound," as dreamed by Farishta, is imaginatively reconstructed from historical accounts of Muhammad and the beginning of Islam in Mecca. The choice of "Mahound" for the Prophet's name, as an adoption of the derisive European version of Muhammad, is offensive in itself, though the text complicates this characterization by adding disclaimers that the naming is strategic: "To turn insults into strengths, whigs, tories, Blacks all chose to wear with pride the names they were given in scorn ...."37

Rushdie's treatment of the "satanic verses" also offended. Briefly, the satanic verses episode, ${ }^{38}$ as told by the tenth-century historian Tabari, refers to Muhammad's acceptance, under Satanic deception, of three female deities from the prevailing polytheistic religion in Mecca-an acceptance later recanted when the Archangel Gibreel advises Muhammad of Satan's trickery. Most Muslim scholars regard the Qur'an ${ }^{39}$ in its entirety as the word of God dictated to Muhammad by the Archangel, and the compromising satanic verses as apocryphal, even as a convenient tool for "orientalist" revision of Islamic history. ${ }^{40}$ Rushdie's primary offense is that he invoked these verses at all."

he had had of a "devil-angel relationship [that] would be suraightforward." Sean French. Talks to Salman Rushdie, OBSERVER (London), Sept. 25, 1988, at 43, reprinted in THE RUSHDIE FILE supra note 6, at 6. 7; cf. RUSHDIE, THE SATANIC VERSES, supra note 1, at 424 ("What follows is tragedy.-Or. at least the echo of tragedy, the full-blooded original being unavailable to modern men and women . . . .). But $c f$. Stephen A. Landsman, Satanic Cases: A Means of Confronting the Law's Immoraliny, 66 Notre DAME L. REV. 785, 790 (1991) (arguing that, because The Salanic Verses portrays characters "in posituons not unlike the ones young lawyers are likely to face," novel has didactic moral value for lawyers confronting "temptation" and "moral risk").

35. See Slaughter, supra note 14, at 168 (quoting Rushdie and citing Muslim enticasms of these characterizations).

36. Portions of my description of the book's offensive sections have been substantially adapted from the archival work of others. See PIPES, supra note 9, at 53-69: Slaughter, supra note 14, at 161-69.

37. RUSHDIE, THE SATANIC VERSES, supra note 1, at 93; cf. RUSHDIE, In Good Fath, supra note 27. at 402 (pointing to "Mahound" controversy as "instance in which de-contextualization has crealed a complete reversal of meaning").

38. See generally F.E. PETERS, MUHAMMAD AND THE ORIGINS OF ISLAMI 160-62 (1994) (apparently accepting incident as historically truthful). For accessible introductions to Islamic history and thought, see

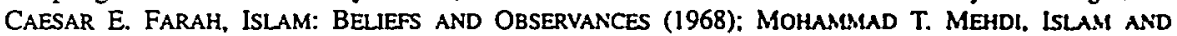
INTOLERANCE: REPLY TO SALMAN RUSHDIE 14-31 (1989).

39. The Qur'an (anglicized Koran) is the sacred text of Islam.

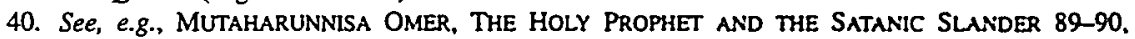
101-06 (1989); M.M. Ahsan, The "Satanic" Verses and the Orientalists. HAMDARD ISLAlucus. Spring 1982, at 27 (1982), reprinted in SACRILEge Versus CIVILTTY: MUSLuM PERSPECTIVEs on The SATANiC VERSES AFFAIR 131 (M.M. Ahsan \& A.R. Kidwai eds., rev. ed. 1993) (hereinafter SACRILEGE). The word "orientalist," meaning a student of oriental culture, connotatively describes one who recreates the "orient" (e.g., as "backward" or "exotic") for Westem imperialist fancy, See generally EDWARD W. SAID. ORIENTALISM (1978).

41. A recurring trend in Muslim writing critical of Rushdie is a characterization of him as Anglophile and orientalist "wanna-be." Ausaf Ali. The Westemization of a Nice Mfuslim Boy, UNIVERSAL MESSAGE, Mar. 1991, at 25; Shahabuddin, supra note 13, at 39 ("Rushdie . . . has to brag . . so that he can convincingly vend his Islam wares in the West . ..."); see also "Simon Rushron" ato Salman Rushdie. 
But The Satanic Verses reimagines Tabari's account with other, overtly blasphemous interpretations. First, it is unclear whether Gibreel is in control of Mahound or vice versa; ${ }^{42}$ second, it is clear that Gibreel/Mahound, not Satan, are responsible for "both the statement and the repudiation" of the satanic verses; and third, it is suggested that Mahound later invents the diabolic origins of the satanic verses to mask the truth. ${ }^{43}$

In the story of "Ayesha," with overpowering femininity that is ultimately traceable to the central conflict between Allah and the three female deities from the satanic verses. Ayesha, a young prophetess (and namesake for Muhammad's/Mahound's favorite wife), is inspired by the Archangel Gibreel to lead her followers into the Arabian Sea, which will miraculously part and convey them to Mecca. The story borrows from an actual incident in Karachi in the early 1980's, when several pilgrims willingly drowned themselves behind a Shiite woman promising to lead them to the holy city of Kerbala in Iraq. Associating a figure of popular superstition with the Prophet's favorite wife means, to Muslim readers, profaning Ayesha's name. ${ }^{45}$ Some also inferred a sly aspersion on Islam, and religion generally, as derivative of and culminating in fanaticism. ${ }^{46}$

The brothel episode dreamed by Farishta ${ }^{47}$ is perhaps the most potently offensive. Prostitutes in a brothel in Jahilia (the fictional equivalent of Mecca) improve their business when they take on the names and manner of the Prophet's twelve wives. They are eventually executed for their actions, but the damage, from the point of view of Muslim readers, has undeniably been done.

Condemning Rushdie for The Satanic Verses requires deciding whether or not fiction is a factitious cover for malicious diatribe. The answer is far from easy, but no straightforward diatribe could have offended more easily. The Satanic Verses is everywhere alive to its own meaning, profaning with

in SACRILEGE, supra note 40, at 65, 67 ("His detractors anglicise his name to Simon Rushton."). But see TIMOTHY BRENNAN, SALMAN RUSHDIE AND THE THIRD WORLD: MYTHS OF THE NATION 32-78 (1989) (situating Rushdie as anticolonial and postcolonial writer); Salman Rushdie, Choice Between Light and Dark, OBSERVER (London), Jan. 22, 1989, at 11, reprinted in THE RUSHDIE FILE, supra note 6, at 61, 62 ("[T]he saddest irony of all . . . [is] that after working . . . to give voice and fictional flesh to the immigrant culture of which I am myself a member, I should see my book burned, largely unread, by the pcople it's about . . . ."). But cf. Feroza Jussawalla, Resurrecting the Prophet: The Case of Salman, the Otherwise, 2 PUB. CULTURE 106, 111 (1989) ("Thus, we see the failure of paradigmatic approaches: the anti-Orientalist has turned into an Orientalist!"); Alex Knonagel, The Satanic Verses: Narrative Structure and Islamlc Doctrine, 18 INT'L FICTION REV. 69, 73 (1991) ("While the novel manages to arouse the reader's anger against oppression, it undermines this anger at the same time by ridiculing its victims."); Ali A. Mazrui, Witness for the Prosecution: A Cross-Examination on The Satanic Verses, THIRD TEXT, Summer 1990, at 31,33 ("II]t is not unusual for a person to be anti-imperialist in a general sense and yet a racist at the same time.").

42. RUSHDIE, THE SATANIC VERSES, supra note 1 , at $110,112,122$.

43. Id. at $123-25$.

44. Id. at $216-40,473-507$.

45. See Slaughter, supra note 14 , at 169-70.

46. Id.; see also AKHTAR, supra note 20, at 29.

47. RUSHDIE, THE SATANIC VERSES, supra note 1 , at 380-92. 
ambiguous purpose but with full mindfulness. It only injures so well because it assaults so knowingly.

\section{WhY the RuShDIE INCIDENT Has ANYTHING TO SAY ABOUT LAW AND LITERATURE}

Empowered and sustained by the media, the Rushdie incident is a media production. ${ }^{48}$ Because it so palpably regards legal reception of literature, it must have some commonsensical relevance to the law-and-literature movement. Furthermore, partly because it is a media production, the incident itself is at once like literature and like law (or "trial").

The manner in which the media has presented and debated the Rushdie incident is trial-like. Trials, one can say without overreaching, often serve cultural purposes, cathartic or otherwise. ${ }^{49}$ Publicized trials may have an element of the theatrical, dramatizing adversaries to ascribe mythic or symbolic values to events. In such large-scale productions of cultural meaning through legal process, the media's participation as medium is understandably thick.

To be sure, media intervention, no matter how trying for people and ideas in the public eye, does not automatically amount to a legal trial. The Rushdie incident itself is not a grand confrontation between free expression and fundamentalism in some officially capable and international legal forum-even if it is undoubtedly peppered with isolated applications of legalistic rhetoric. ${ }^{\text {so }}$ The apparent inability of pluralism and fundamentalism to meet on common legal ground has to do with jurisdictional and political feasibilities in contemporary international order. To the extent that this failure to universalize law is a function of discursive disparities between "East" and "West," it has similarities with what Sara Suleri identifies as the "essential alegality" and "radical obsolescence [of law]" in colonial discourse, i.e., with the failure of colonial regimes to legitimize themselves in the legal precedent of either Western colonizer or Oriental colonized. ${ }^{51}$

48. Indeed, the fatwa itself derives its particular ability to sentence from media dissemination. I use the present and present perfect tenses to describe the Rushdie incident in the belief that. for both Rushdie and his punishers, the incident remains almost as relevant in the present as it was six years ago. Cf. Henry L. Gates, Jr., The Empire Writes Back: Worlds Collide in Salman Rushdie's New Collection. NEW YORKER. Jan. 23, 1995, at 91, 92 ("If Rushdie's persecutors have made the experience of rootless nomadism all too literal for him, he's still teaching the rest of us why we can't go home again.").

49. I am indebted to Professor Robert Ferguson for this observation. Interview with Robert Ferguson. Professor, Columbia University School of Law, in New Haven, Conn. (May 4. 1994).

50. For uses of the "trial" metaphor within the Rushdic incident see Mazrui. supra note 41. at 31: Stephanie Newell, The Other God: Salman Rushdie's "New" Aestheric, I LTERATURE \& Hist. 67. 73 (1992) ("The trial-by-fiction of Koran undertaken by Rushdie has Westem Orientalism at its roots ....").

51. SARA SULERI, THE RHETORIC OF ENGLISH INDIA 55-56 (1992). Suleri finds, upon reading the trial of Warren Hastings, that Hastings' accusers were thetorically compelled to differentiate their own legal authority from Hastings' pernicious use of colonial power to ill effect; else the colonial enterprise itself would have been inculpated in Hastings' apparent irrationality. The source of their anxiety was that siding against Hastings also meant siding against their own rational legal order. It seems reasonable to wonder whether Suleri's reading might apply to other jurisprudence that answers historical examples of prejudiced 
But in another sense, if Rushdie and his adversaries are not actually on trial in the Rushdie incident, they nevertheless might as well be. Like a trial, the Rushdie incident pares down individuals and ideas with internally complex, ambiguous life stories to produce wieldy but simplistic plaintiff-defendant oppositions. ${ }^{52}$ Like a trial, it appears to be a cultural mechanism that replaces and cheats complex cognition with facile, authoritative differentiation. Still, the Rushdie incident is a trial-by-media; judgment within it is effectively dissipated through scattered, nonauthoritative texts. But the dichotomous categories necessary for quick (perhaps unjust) judgment nonetheless control meaning and derive authority in aftereffect. Adversarial antagonism between fundamentalist condemnation and pluralist protection of free speech remains a prominent interpretive key to the incident. Yet, not only are there differences within Islamic law, ${ }^{53}$ and not only is Khomeini's interpretation contestable within Islamic law itself, ${ }^{54}$ but the tradition of heretical literature within Islam (and public tolerance of it) dates back at least to the ninth century. ${ }^{55}$ Nor is The Satanic Verses collapsible into a version of antireligious free speech, because Rushdie's intention from the beginning has apparently been just the opposite: to get inside what it means to have religious experience, instead of providing an easy "secular sneer." 56

adjudication by rigorously privileging universally applicable neutral principles over the kind of openly ideological articulation of law that could theoretically both legitimate and counteract existing inequities. See id. at 53 ("The lie of the impeachment proceedings is thus its failure to admit that Hastings' misdeeds were merely synecdochical of the colonial operation, that to assume that such governorship could take more palatable form was to allow Burke to have his cake of astonishment and to eat it, too."); $c f$. Samuel $P$. Huntington, The Clash of Civilizations?, FOREIGN AFF., Summer 1993, at 22, 40-41 (discussing fundamental difference between contemporary Western and Eastern cultural ideals and noting that ideal of "universal civilization" may itself be Westem). But of. Ann Elizabeth Mayer, Universal Versus Islamic Human Rights: A Clash of Cultures or a Clash with a Construct?, 15 MiCH. J. INT'L L. 307, 309-20, 341 (1994) (disagreeing with Huntington's claims about Islamic culture).

52. Cf. John T. NoONAN, JR., PERSONS AND Masks of THE LAW 4 (1976) ("The paradigm of law is trial before a court. For almost a century the chief business of American lawyers has been elsewhere."); id. at 113 (suggesting that absence of personal details may give legal recitation of facts "timeless quality").

53. See Moncef Marzouki, Au Nom d'Allah? [In the Name of Allah?], LE MONDE (Paris), Feb. 25. 1989, at 2, reprinted and translated in THE RUSHDIE FILE, supra note 6, at 131 ("Khomeini represents only a fraction of the whole, Shi'ism, and only one group in this fraction, the clericalism of the extreme right."). Even the "fundamentalist" label may not apply perfectly to some of the prominent fundamentalists in the Rushdie incident. See RUTHVEN, supra note 20, at 123 (discussing Shabbir Akhtar). In this Note, the word "fundamentalist" is not meant pejoratively.

54. See, e.8., Al-Azm, supra note 20; Mayer, supra note 20.

55. See Saadi A. Simawe, Rushdie's The Satanic Verses and Heretical Literature in Islam, 20 IowA REV. 185, 186 (1990); $c f$. RUSHDIE, In Good Faith, supra note 27, at 409 ("Islam contains the doubts of Iqbal, Ghazali, Khayyám as well as the narrow certainties of Shabbir Akhtar of the Bradford Council of Mosques .....").

56. See PIPES, supra note 9, at 55; Salman RUSHDiE, "In God We Trust", in Imaginary HOMELANDS, supra note 27 , at 376,376 ("The rationalism of . . . [literary realism] comes to seem like a judgment upon ... the religious faith of the characters being described."); French, supra note 34, at 43, reprinted in THE RUSHDIE FILE, supra note 6, at 7 ("I don't believe that angels appear and talk to people. On the other hand, revelation seems to me to be genuine."' (quoting Rushdie)); $c f$. Slaughter, supra noto 14, at 201 (noting "irony" in similarity between Rushdie's project as writer and Muslim resistance to liberalism); Sara Suleri, Contraband Histories: Salman Rushdie and the Embodiment of Blasphemy, 78 YALE REV. 604, 606-07 (1989) (finding that, in reinstalling sacred and profane as relevant categories, 
The sense of "trial" that follows from a commonsensical, perhaps liberal, ${ }^{57}$ idea of "law" implicates a ritualistic, case-by-case legal process, where opposing sides are allowed to present their stories under formal constraint. This sense of trial fails to describe the Rushdie incident, for in legal pronouncements against the novel, neither Rushdie nor his detractors have been given a meaningful equivalent of prejudgment due process. ${ }^{58}$ Where a trial imports an expected constraint and rhythm, ${ }^{59}$ the Rushdie incident is disruptive precisely because the international impact of Iranian legal interpretation has been so unconstrained and unexpected.

On the other hand, a trial has a wholeness that allows it to contain differing narratives under one organizing principle. The same has been said about "law," and could be said about the manner in which the Rushdie incident contains its component narratives:

[T] he whole of law is the production of one narrative after another. ... [E]ach individual focus ... will have unique features that set it apart. Nevertheless, the unity of law as a discursive enterprise will be the primary element of narrative and will lie at the center of arguments over the point of law. ${ }^{60}$

Structurally, containment implies misrepresentation of the individual components in the composite final product, and in the Rushdie incident, the media is the visibly responsible culprit for any disparities between popular perceptions and literary or legal realities. Misrepresentation may not mean complete falsification and need not call for paranoic resistance to the media. ${ }^{61}$ Rather, misrepresentation by the media means mythification of historical truth into cultural meaning. ${ }^{22}$ When "mediated," the primary legal and literary texts within the incident emerge as more distinct and one-sided than close reading or historical explanation reveals. Rushdie himself has banally participated in

Rushdie has written "a deeply Islamic book," and that Rushdie's blasphemy should be "reread as a gesture of reconciliation toward the idea of belief").

57. According to Bruce Ackerman, constrained dialogue (of the son trials replicate) is (or should be) the defining principle for the "liberal" way of organizing conflict. See generally BrUCE A. ACKERMLAN, SOCIAL JUSTICE IN THE LIBERAL STATE (1980). The adversarial model does not account for criminal procedure that is based on an inquisitorial system.

58. Cf. E.L. Doctorow, Statement at Public Meeting (Feb. 22, 1989), in THE RUSHDiE FILE, supra note 6 , at 159 (noticing that death sentence is "without trial").

59. Interview with Robert Ferguson, supra note 49.

60. Dennis M. Patterson, Law's Pragmatism: Law' as Practice \& Narratue, 76 VA. L REV. 937, 989 (1990) (using proposition to argue that legal rules receive meaning from being embedded in tredition of legal practice, and that change in law comes from within this practice).

61. See, e.g., Douglas Rushkoff, Media Virus! Hidden agendas Is Popular Culture $41-42$ (1994) (noting suggestion that Rushdie's agent had sent copy of The Saranic Verses to Khomeini with hope of thereby increasing sales).

62. See Kendall Thomas, Strange Fruit, in RACE-ING JUSTICE, EN-GENDERING POWER: ESSAYS ON ANITA Hill, Clarence thomas, and the Construction of SOCial, Realtiy 364, 364-65 (Toni Morrison ed., 1992) (quoting Roland Barthes). 
this simplistic typology, becoming in turn the secular free-speech advocate ${ }^{63}$ and the devout convert to Islam. ${ }^{64}$ Both of these self-contained postures seem utterly inadequate compared to the novel's redoubling ironies, its dexterous avoidance and complication of every possible stance or meaning that might be ascribed to it. ${ }^{65}$ In keeping with Charles Baudelaire's conception of irony, ${ }^{66}$ the novel refuses any kind of dialectical progression from naive to wellconsidered positions, laughing at fool and philosopher alike as a way of asserting the inauthenticity of both without sanctioning any particular alternatives. When Rushdie's novel taunts, jeers, or laughs, it does not laugh from a position of greater wisdom; rather, it questions the very possibility of wisdom. The subsequent media version of "Rushdie," in a mockery of justice to his own novel, simply alternates between more or less laughable roles.

As a consequence, sides are taken very easily in the Rushdie incident, even where neither side was neatly one-sided ex ante. Sara Suleri writes that " $[t]$ he internal dangers of [The Satanic Verses] are . . . externalized, or rendered unto Iran." No doubt the "internal dangers" of the Islamic side are also externalized within the incident into an opposing "free speech" camp. Thus, if Barbara Johnson is right to say that characteristic of legal judgment is the forcible transformation of internal ambiguity (or "differences within") into more adjudicable "differences between,"68 and if the function of "trial" is to

63. Rushdie, An Open Letter, supra note 13, at 34-35 ("These persons, whom I do not hesitato to call extremists, even fundamentalists, have ... [stated] that they had no need actually to read [the book]. . . . The right to freedom of expression is at the very foundation of any democratic society ...."). One Muslim respondent implored Rushdie not to be led by his fellow writers, for whom "'freedom of expression has become a fetish." John Ezard, Rushdie Urged To Withdraw Book and "End Suffering", GUARDIAN (London), Mar. 7, 1989, at 2, reprinted in THE RUSHDIE FILE, supra note 6, at 124, 125 (quoting Hesham El-Essawy of Islamic Society for Religious Tolerance in the U.K.). But cf. RusHDIE, In Good Faith, supra note 27, at 396 ("I have never seen this controversy as a struggle between Westem freedoms and Eastern unfreedom.").

64. SALMAN RUSHDIE, Why I Have Embraced Islam, in IMAGINARY HOMELANDS, supra note 27, at 430. Rushdie has since reverted back to a less conciliatory position. See Salman Rushdic, One Thousand Days in a Balloon, in THE RUSHDIE LETTERS, supra note 13, at 13, 23 (describing failure of reconciliation attempt with six Islamic scholars).

65. Cf. Homi Bhabha, NEw STATESMAN (London), Mar. 3, 1989, reprinted in THE RuSHDie FILE, supra note 6, at 112,113 ("The complex vision of Satanic Verses is fast losing its reality . . . [and] being reduced to empty symbols . . . that at the same time are the prisoners of a Western liberal conscience and hostages to an Islamic fundamentalist orthodoxy."); John O. Voll, For Scholars of Islam, Interpretation Need Not Be Advocacy, CHRON. OF HIGHER EDUC., Mar. 22, 1989, at A48 (discussing urge to abandon considered interpretation for side-taking or "advocacy" in "heat of the debate" over Rushdie incident).

66. For a fuller discussion of Baudelaire's conception of irony, as expressed in his essay De l'Essence du Rire, see PAUL DE MAN, The Rhetoric of Temporality, in BLINDNESS AND INSIGHT: ESSAYS IN THE RHETORIC OF CONTEMPORARY CRITICISM 187, 211-16 (rev. ed. 1983). In the same essay, Baudelairc writes, "Laughter is satanic: it is thus profoundly human." CHARLES BAuDELAIRE, On the Essence of Laughter and, in General, on the Comic in the Plastic Arts (1855), reprinted in THE PAINTER OF MODERN LIFE AND OTHER ESSAYS 147, 153 (Connoisseurship Criticism and Art History in the Nineteenth Century, Jonathan Mayne ed. \& trans., 1964).

67. Suleri, supra note 56 , at 605 .

68. BARBARA JOHNSON, Melville's Fist: The Execution of Billy Budd, in THE CRITCAL DIFFERENCB 79, 105-07 (1980); see also Weisberg, supra note 3, at 34-36 (discussing Johnson's essay in law-andliterature context and noting her conclusion that "function of [legal] judgment is to turn the ambiguous into the decidable"); $c f$. NOONAN, supra note 52, at 113 (discussing legal simplification of facts). 
accomplish this differentiation into opposing sides, then the media-created Rushdie incident is like "trial" in a very important sense. If so, then the simplistic typology of the media incident may derive from the constraints on a legal trial imposed by the local generic forms available to speakers' and observers' consciousness and subconsciousness. Because culture has to be ready for the story told by a trial, it influences, often by the literary genres it has already absorbed, the kind of story that the trial ends up becoming. ${ }^{6}$

Of course, when many generic forms are available (given an international and not a local community trial), ${ }^{70}$ generic simplification is not necessarily prefigured, unless media representation itself is constrained by internal generic pressures, which it very well might be. What Sara Suleri calls "journalistic oppositions between fundamentalism and secularism"71 are partly just that-journalistic oppositions. Even if the medium is not the message, it at least affects the message. But usual journalistic opposition is compounded in the Rushdie incident, and trial metaphors within it ${ }^{72}$ bespeak greater truths about what the incident itself means for the nature of legal, and not just journalistic, understanding. Being "trial-like," the incident stands only tropologically for trial and judgment on Rushdie and Islam, but as a metaphor for law, it is telling and powerful.

Moreover, trial-form narratives like the Rushdie incident may take representational cues from available literary narratives and genres-the genre of postmodern satire (as exemplified by Rushdie, Pynchon, ${ }^{73}$ and others) being among those available in this case. But the capacity for selection from available forms may be constrained by a genuinely different logic. As a legal narrative, the Rushdie incident simplifies "differences within" The Satanic Verses (as well as other texts) to produce dramatic but inaccurate oppositions. The result is a visible generic difference from the central literary narrative, a difference that comes across as gross simplification and bad faith.

Yet the Rushdie incident is also like a literary narrative in its uncanny, almost methodical repetition of the same issues at stake in The Satanic Verses-whether an idea compromises when weak and tolerates when strong, ${ }^{74}$ whether the profane has not a parasitical but an essential relation to

69. See Robert A. Ferguson, Story and Transcription in the Tnal of John Brown. 6 Y ALE J.L. \& HUMAN. 37, 73 (1994) (discussing hidden presence of genre in transeription and interpretation of tral event); cf. TZVETAN TOdorov, MikHaIl BaKHTIN: The DIALOGIC PRINCIPLE 82-85 (Wlad Godzich tuns., 1984) (explaining Mikhail Bakhtin's conception of "genre" as framework that dominates understanding and representation of social reality).

70. Cf. Richard A. Matasar, Trial Narratives and the Study of Law: Some Questions, 76 IOWA L. REV. 207, 220 (1990) (reviewing POPULAR TRIALS: RHETORIC, MASS MEDIA, AND THE LAw (Roben Hanman ed., 1990)) ("What do . . trial participants intend to say? . . Who is their audience? Is it the jury? The press? Local society? National audiences? The world?").

71. Suleri, supra note 56 , at 605 .

72. See supra note 50 .

73. See, e.g., ThOMAS PyNChON, THE CRYing of LOT 49 (Bantam Books 1981) (1966).

74. See RUSHDIE, THE SATANIC VERSES, supra note 1, al 95, 121. 126, 335, 467: see also Bandung File: Interview with Salman Rushdie, supra note 11, at 22 ("[W] hen you're weak, do you compromise: 
the sacred as the Orient to the Occident, ${ }^{75}$ and so on. The media incident and the book are often thematically indistinguishable, the literary narrative evidently so overdetermined that it has determined its own reception. As Rushdie observed, the characters in the novel are "struggling with just the sort of great problems that have arisen to surround the book." The Satanic Verses occasionally even acquire a discomforting prescience in hindsight." When "life imitates art," the processes by which "life" is manufactured may themselves be artful. One author expresses the common feeling that the "dialogue between Rushdie and the infuriated Muslims, which has now been broadcast internationally, and in which the boundaries between fiction and reality are almost totally obliterated, may be read as the most compelling, though unwritten chapter of the novel."78 But even if the incident repeats the complicated issues raised in the book, it repeats them simplistically, within a more trial-like setting. As such, it presents interpretive issues too strenuous for the cognitive and representational capabilities of its own medium, and enacts a difficult marriage between law and literature that makes it relevant to any scholarly enterprise positing an essential or potential rapprochement between the two. A casualty of this strange admixture is that the task of reading the incident as a whole seems both deceptively simple and unnecessarily complex. Legal and literary tropes both succeed too well in describing the Rushdie incident; as a result, they also narrate the uncertainty at their mutual disciplinary boundaries.

If the Rushdie incident is itself a media-created, trial-like "legal narrative," it is not merely collapsible into the legal or legalistic narratives (e.g., the fatwa and Indian ban) it contains-just as it is not collapsible into The Satanic Verses. The incident only derives its particular authority as law-and-literature parable by being, in itself, both legalistic and literary. Yet, the incident also repeats the logic of its texts, for what it reveals is a similar interaction between the primary legal and literary narratives it contains, meaning a simplification and an appropriation for indecorous ends that each side effects on the other when it speaks on its own. The law and literature within the Rushdie incident are therefore both alike and at odds. Sometimes indistinguishable in power and

when you're strong, are you tolerant?").

75. See RUSHDE, In Good Faith, supra note 27, at 401 ("I sought images that crystallized tho opposition between the sacred and profane worlds.").

76. Id. at 394.

77. See, e.g., RUSHDIE, THE SATANIC VERSES, supra note 1, at 272 ("The film was to be .. the story of the encounter between a prophet and an archangel ... . But would it not be seen as blasphemous ... . ."); id. at 374 ("Your blasphemy, Salman, can't be forgiven. . . . To set your words against the Words of God."); id. at 545-46 ("Salahuddin was thinking . . . about how he was going to dio for his verses, but could not find it in himself to call the death-sentence unjust."); $c f$. RUSHDIE, In Good Faith, supra note 27, at 407 ("[S]ome passages in The Satanic Verses have now acquired a prophetic quality that alarms even me.").

78. Simawe, supra note 55, at 189-90; cf. Marlena G. Corcoran, Salman Rushdie's Satanic Narration, 20 IOWA REv. 155, 158 (1990) ("In The Satanic Verses,] we find inscribed versions of the very controversy over sacred and profane writing which has so colored the reception of the book."). 
effect, they nevertheless compromise each other-law simplifying literature to achieve legal pronouncement, ${ }^{79}$ literature overstating its quasi-legal powers to compete with law. ${ }^{80}$ The remainder of this Note will explicate the various compromises at the law-literature boundaries within the Rushdie incident.

\section{READ ALERT: LITERARY NARRATIVE as NARRATtVe EVIDENCE}

Simplification is necessary for legal pronouncement against The Satanic Verses because "reading" for legal purposes is different from reading for literary purposes. As far as relative conceptions of reading are concerned, the Rushdie incident is a parable for a terrible gap between law and literature. All the legal narratives within it are conclusory, and because they must use a literary narrative as evidence for their conclusions, they compromise literary reading to align literary narrative toward their own teleological ends, even when it is resistant to such realignment.

The best way to compromise literature is not to read it, or to paraphrase it. $^{81}$ Literary understanding is impossible without a minimal submission to the literary medium, the text itself. Not surprisingly, the early stages of the media incident showed Rushdie copiously chiding his critics for not having read his book. "It is not . . the book it has been made out to be," he wrote in a 1990 essay, "that book containing 'nothing but filth and insults and abuse' that has brought people out on to the streets across the world. That book simply does not exist." ${ }^{83}$ Some of Rushdie's distress was clearly coming from different reading priorities: "It has been bewildering to learn that people . . . have been willing to judge The Satanic Verses and its author, without reading it . . . It has been bewildering to learn that people do not care about art." He went on to provide a plot summary from his viewpoint, ${ }^{85}$ intended to "replace the non-existent novel with the one I actually wrote," nevertheless that the reading priorities were unbridgeably far apart, and that legally potent simplifications had irretrievably influenced the tone of the rest of the media controversy:

There are times when I feel that the original intentions of The Satanic Verses have been so thoroughly scrambled by events as to be lost for ever ... [,] that the terms in which the novel is discussed seem to

79. See infra part III.

80. See infra part IV.

81. Cf. CLEANTH BROOKS, THE WELL-WROUGHT URN 192 (1947) (stating similar proposition with regard to poetry in chapter entitled "The Heresy of Paraphrase").

82. See, e.g., Bandung File: Interview with Salman Rushdie, supra note 11, at 23; Rushdie, An Open Letter, supra note 13 , at 34 .

83. RUSHDIE, In Good Faith, supra note 27, at 395.

84. Id. at 397.

85. Id. at $397-403$.

86. Id. at 397. 
have been set exclusively by Muslim leaders (including those . . . who can blithely say . . . "Books are not my thing"). ${ }^{87}$

Typical of the Muslim rejoinder to Rushdie's initial protests was that of Syed Shahabuddin, Muslim MP in India:

Yes, I have not read it, nor do I intend to. I do not have to wade through a filthy drain to know what filth is. My first inadvertent step would tell me what I have stepped into. For me, the synopsis, the review, the excerpts, the opinions of those who had read it and your gloatings were enough. ${ }^{88}$

Shabbir Akhtar, spokesman for the Muslim community in Bradford, ${ }^{89}$ repeated the point bluntly, using an analogy nothing short of stunning:

[I]t is not a necessary condition of having knowledge of a work that one should have read it, any more than it is necessary for a judge to witness a murder in order to pass judgment. The ordinary Muslim went by the verdict of those trusted religious and other learned authorities who had read the whole book, much as a judge goes by the evidence supplied by eye-witness accounts. ${ }^{90}$

Not reading, it seemed, was the peculiar province of law. ${ }^{91}$ Instead of being hearsay, authoritative reading had preemptive and precedential value, as both a "verdict" already rendered and the paraphrastic "eyewitness" evidence behind dissipated companion verdicts. Authoritative reading also signified, quite appropriately, something like reasoned trial; but the principle for later interpretation was deferential, in the sense that subsequent trial and judgment could risk referring back respectfully to the original. Despite Rushdie's anxious reminders that the novel's irony was not directed against religious faith, or that the profanity was mouthed by unreliable characters and therefore not expressive of authorial intention, ${ }^{92}$ many Muslims remained unconvinced. ${ }^{93}$

There are very good arguments that a close reading of The Satanic Verses would (and did) produce just as much offense as no reading at all. Assuming, however, that a close reading would yield different judgments (as Rushdie's frustration suggests), reading for the purpose of legal condemnation obviously

87. Id. at 403.

88. Shahabuddin, supra note 13 , at 39.

89. See supra text accompanying note 15 .

90. AKHTAR, supra note 20, at 40 . This passage is almost more interesting for the imperfections in the metaphor. Note that the judicial "verdict" has already been passed by "religious and other learned authorities" before the case reaches the "ordinary Muslim" judge.

91. But cf. John D. Calamari, Duty To Read-A Changing Concept, 43 FordHAM L. Rbv. 341 (1974) (discussing contract law doctrine imposing duty to read).

92. RUSHDIE, In Good Faith, supra note 27, at 397-403.

93. See, e.g., infra notes $144-45,147$ and accompanying text. 
requires a different interpretation of the original evidence (the literary text)-a different story about the story. But, as Rushdie seems to urge, the literary text itself ${ }^{94}$ should be able to offer some authoritative guidelines about how it should be interpreted. A literary narrative is "emplotted" in a certain way. Events follow one another in a certain sequence; words are used with certain denotations and perhaps ironic connotations. These elements make up the plot and its signification, the story that is being told. ${ }^{95}$ Certainly, the meaning of a particular plot sequence or of a particular word is often ambiguous. But if Rushdie correctly complains that legal condemnation of his story would have been on less sure footing after close reading, then the story presumably directs its own interpretation with a firm hand nevertheless.

One could deduce that the narrative's literary status made its selfinterpretation irrelevant to legal judgment. Yet, a part of the law-and-literature movement seems to derive its seriousness in claiming a connection between law and literature from an implied or express "narrativity" about law if Roland Barthes has identified narrative as precisely that form which is not fixed as "literature." 97 It has been argued, for example, that law can gain from literature an empathic understanding that comes out of reading narrativized experience, ${ }^{98}$ and that courtroom evidence is most reliable as particular, individualized, and experiential narrative. ${ }^{99}$ In shor, law is said to

94. The idea of an isolatable "literary text itself" is naive. But further definition is beyond the scope of this Note.

95. I am simplifying the idea of "emplotment." Hayden White calls it the process of arranging events "in a series that is at once chronologically and syntactically structured, in the way that any discourse from a sentence all the way up to a novel is structured." Hayden White. The Historical Texs as Literary Artifact (1974), reprinted in CRITCAL THEORY SINCE 1965, at 395. 402 (Hazard Adams \& Leroy Searle eds., 1986).

96. See generally Marie Ashe, The "Bad Mother" in Low and Literature: A Problem of Representation, 43 HASTINGS L.J. 1017, 1030 (1992) (positing importance of literary narrauve in displacement of stereotypes); Cover, supra note 22, at 5 ("In this nomative world, law and narrative are inseparably related."); William N. Eskridge, Jr., Gaylegal Narratives, 46 STAN. L. REV. 607 (1994) (responding to critique of legal storytelling movement by Daniel Farber and Suzanna Sherry): Robin West. Jurisprudence as Narrative: An Aesthetic Analysis of Modem Legal Theory, 60 N.Y.U. L REV. 145 (1985) (advocating reading of legal theory as form of narrative and recognizing aesthetic dimension of legal debate).

97. ROLAND BARTHES, IMAGE-MUSIC-TEXT 79 (Stephen Heath trans., 1977) (“[N]arrative is present in myth, Iegend, fable, tale, novella, epic, history, tragedy, drama, comedy, mime, painting . . . . stained glass windows, cinema, comics, news item, conversation.").

98. See, e.g., Robin West, Economic Man and Literary Woman: One Contrast, 39 MERCER L REV. 867,875 (1988).

99. See Laurence H. Tribe, Trial by Mathematics: Precision and Rirual in the Legal Process, 84 Harv. L. REV. 1329, 1349 (1971). Admittedly. Tribe did not intend to comment about relations between law and literature. But his preference for narrative evidence easily leads into work like Robin West's. See Robin L. West, Taking Preferences Seriously, 64 TUL L. REV. 659, 665, 686 (1990) (emphasizing importance of particular, concrete stories in case-by-case adjudication); cf. WILLLAM TWINING. RETHINKING EVIDENCE: EXPLORATORY ESSAYS 223 (1990) (identifying particularity as necessary element of legal "stories"): Daniel A. Farber \& Suzanna Sherry, Telling Stories Out of School: An Essay on Legal Narratrves, 45 STAN. L. REV. 807, 811 (1993) (linking feminist commitment to particularity with legal storytelling movement); Richard K. Sherwin, The Narrative Construction of Legal Realiry. 18 Vr. L REV. 681 . 685 (1994) ("The new discourse comes from scholars who study particular legal contexts and who seck to give life to particular (often unheard) voices and dramas in the legal culture."). 
be like literature in that it has good use for narrative-a legal pronouncement is usually backed (or should be) by a story, a historical explanation based on the evidence at hand. ${ }^{100}$ As J. Hillis Miller puts it, "the just application of the law depends on getting a story straight about what happened .... The appeal to precedent in law means, most often, the appeal to an agreed-upon narrative ....,101

But what the Rushdie incident seems to show is that it is not enough, in establishing a law-literature rapprochement, to say that law makes use of narrative, because different kinds of narrative make all the difference in the world. For legal narrative, the relevant question in the Rushdie incident is evidentiary in character-how should evidence be read and reconstructed to support the legal narrative legitimating the legal judgment that draws from this evidence? This kind of reading may have an antithetical relation to reading in the literary sense, especially when the evidence to be read is itself a literary narrative. Though judgments about literary reading are matters of opinion, the Rushdie incident shows that law can do injustice to literature by misrepresenting it, by imposing on literature a distant, other logic. The word "justice" itself, like the word "representation," has both aesthetic/mimetic and politico-legal meaning. ${ }^{102}$ As Pygmalion, we look for justice in perfect likeness, in a simulacrum that "does justice to" (or tells the truth about) something else. ${ }^{103}$ As King Oedipus, we may even have to do justice to ourselves for the burdens of statecraft. ${ }^{104}$ If Akhtar's analogy ${ }^{105}$ is extended, however, legal judgment demands interruption and rupture of literary narrative by an other, mediating interpretive narrative that acquires authoritative evidentiary status by re-emplotment and even replacement of the original literary evidence. Justice requires doing injustice to literature.

Yet, the process of constructing coherent legal reality by censoring, subordinating, and highlighting portions of the evidentiary corpus is itself artistic. Constructing a story from an amorphous mass of evidence requires creativity, even inspiration. It may involve censorship in a general sense-parts have to be cut out, other parts emphasized. But literary narratives are themselves guilty of suppressing in order to tell. As the narrator of Shame, one of Rushdie's earlier literary works, puts it, "And now I must stop saying what I am not writing about, because there's nothing so special about that; every

100. Another related similarity between law and literature is that both are rhetorical. See Brook Thomas, Reflections on the Law and Literature Revival, 17 CRITCAL INQUIRY 510, 523 (1991).

101. J. Hillis Miller, Laying Down the Law in Literature: The Example of Kleist, in DECONSTRUCTION AND THE POSSIBILITY OF JUSTICE 305, 306 (Drucilla Cornell et al. eds., 1992).

102. Cf. BARBARA JOHNSON, The Frame of Reference: Poe, Lacan, Derrida, in THE CRITICAL DIFFERENCE, supra note 68, at 110, 11 (punning on legal and mimetic senses of "justice"); PAUL DE MAN, ALLEGORIES OF READING 269-70 (1979) (same).

103. See 1 Robert Graves, THE GREEK MYThS 211 (1955).

104. See 2 id. at 9-15. Oedipus' self-blinding is the traditionally "blind" objectivity of Justice turned inward into heightened subjectivity, i.e., into self-realization and more accurate self-representation.

105. See supra text accompanying note 90 . 
story one chooses to tell is a kind of censorship, it prevents the telling of other tales." 106 The same applies to legal narrative, as Clare Dalton writes (with specific reference to contract doctrine):

The telling of [doctrinal] stories-like the telling of any story-is, in one sense, an impoverishing exercise: The infinitely rich potential that we call reality is stripped of detail, of all but a few of its aspects. But it is only through this restriction of content that any story has a meaning. ${ }^{107}$

Every story must censor to keep its thread and make its point, as also must, in slightly different ways, sentences and words-a cat is called a cat in part to keep it from being identified as a tiger, ${ }^{108}$ a man called a man to keep him from being called a giant. ${ }^{109}$ That there is something artistic about constructing a story from what Dalton calls "the infinitely rich potential that we call reality" seems undeniable. The construction of historical reality from historical evidence is what Hayden White has called the literary or "fictive" aspect of history making, ${ }^{110}$ insomuch as meaningfully emplotting a set of data with ambiguous meaning is itself a primary creative act. The only problem, according to White, is that a set of data can be emplotted in many different ways." ${ }^{111}$ Where no emplotment suggests itself as the superior or correct one, the historian's dilemma is that the story she tells seems like one among many plausible stories that could be told from the same data. There is not enough resistance from the facts.

For White, the process of documenting history is thus literary because historical facts are never enough in themselves to make "history." Similarly, if legal judgment can and should be backed by historical, narrative explanation, ${ }^{112}$ then construction of legal reality from evidence may be one of the most literary aspects of lawmaking. But the Rushdie incident qualifies this leap by showing that when what is being selectively censored and

106. SALMAN RUSHdiE, SHAME 72-73 (Vintage Int'l 1989) (1983).

107. Clare Dalton, An Essay in the Deconstruction of Contract Doctrine, 94 YALE LJ. 997, 1113 (1985); cf. Marianne Wesson, Historical Truth, Narrative Truth, and Exper Testimony, 60 WASH. L. REV. $331,338,346$ (1985) (discussing tendency of expert witnesses to reconstruct events in manner that is "useful" for story being told, at expense of actual, historical truth).

108. My example is an artless reappropriation of a passage from literary theorist Paul de Man. PAUL DE MAN, The Resistance to Theory, in THE RESISTANCE TO THEORY 3, 5 (1986).

109. See JEAN-JACQUES ROUSSEAU, Essay on the Origin of Languages Which Treats of Melody and Musical Imitation, in ON THE ORIGIN OF LANGUAGe 5. 13 (John H. Moran trans., 1966) (using same example to argue for initial figurativeness of language); $c f$. Wlad Godzich. The Tiger on the Paper Mat. Foreword to PAUL DE MAN, THE RESISTANCE TO THEORY, supra note 108, at xiii ("Il]n the play on the size of the cat and on its putative fearsomeness, de Man further alludes to ... the famous passage on the 'giant' in Rousseau .....").

110. White, supra note 95 , at 407 .

111. Id. at 403 ("[T]he series can be emplotted in a number of different ways and thereby endowed with different meanings without violating the imperatives of the chronological arrangement at all.").

112. See supra note 99 and accompanying text. 
highlighted to create legal reality is not "the infinitely rich potential that we call reality" but another literary narrative, ${ }^{113}$ then law and literature seem to diverge. Reconstructing amorphous evidence into a coherent story may be creative in the literary sense, but reconstructing an existing literary story into another coherent story may be barbaric to the existing literary sensibility. When law dominates literature, what White has called the problem of multiple possible emplotments ${ }^{114}$ becomes a problem of multiple possible reemplotments. Even if religiously defined legality chooses a different reemplotment from the one chosen by "liberal" or "public will" legality, the latter will also necessarily re-emplot and compromise the existing literary narrative-accordingly, free speech arguments in the Rushdie incident seem equipped only to misuse and simplify the novel's intimate concern with religious belief. No doubt the legal re-emplotment of literature requires an aggressive reading of literature, possibly even aggressive enough to be a nonreading.

The Rushdie parable teaches that even if law-and-literature scholarship uses "narrative" as a law-literature connecting principle, production of legal narrative may depend on a compromising of literary reading. Such compromise means reconstruction of and violence to literary evidence, though this reconstruction itself is a creative, almost literary act. If law is capable of functioning as a sobering reality principle against literature's overextended reach, then the relationship between law and literature defies any idealistic or transcendental conciliation. Somewhere in the law-literature boundary, there is a frictional resistance; assimilation cannot come without nonideal transaction costs. $^{115}$ Nowhere else is this resistance so foregrounded in a difference between law and literature as where law has to pass judgment on literature.

\section{LITERATURE AS QUASI-LEGAL INSTRUMENT}

Despite this difference, the similarities between literature and lawmaking are also eerily foregrounded as perhaps nowhere else in the Rushdie incident and in Rushdie's roman à clef career generally. In one sense, this is obvious. Rushdie's literature affects people's material lives, just as law does. Péople

113. To be sure, part of the evidentiary corpus justifying legal and nonlegal condemnation of Rushdie has nothing to do with his literary narrative. One seemingly objective source, for example, takes a personal jab: "Rushdie ... has also been mobile with his women." "Simon Rushton" aka Salman Rushdie, supra note 41 , at 67 .

114. See supra text accompanying note 111 .

115. Cf. Godzich, supra note 109 , at xii-xiii ("The term resistance means a property of matter recognized since antiquity: its perceptibility to touch and inertial opposition to muscular exertion. . . . Resistance is a property of the referent, we would say today .....); Duncan Kennedy, Freedom and Constraint in Adjudication: A Critical Phenomenology, 36 J. LEGAL Educ. 518, 526 (1986) ("Resistance or opposition is the characteristic of the law when I anticipate it as a constraint . . . [O]ne of the ways in which we experience law . . . is as a medium in which one pursues a project .... When we approach it this way, law constrains as a physical medium constrains ...."). 
take offense when writers refer to them or their religious heritage explicitly and disparagingly under the guise of fiction. Other writers besides Rushdie have marked society in a similar fashion. ${ }^{116}$ Political fiction (like some of Rushdie's earlier work) treads on especially dangerous ground when it offends in this manner. It can function just like a rival government. In a further sense, such fiction actually competes with the official story, even with history-and since law itself may compete with history by relying on fact-based evidentiary narratives that reread the facts for law's own purposes, ${ }^{117}$ such fiction also competes with law. This Part shows that Rushdie has always aspired to write fiction that competes with history and law in precisely these terms. Yet he has also occasionally emphasized the limitations on fiction imposed by its own fictionality, even if, according to some, he later overused fictionality to predicate polemical retreat after he was placed in a defensive position. While the Rushdie incident powerfully demonstrates that fiction is quite up to the task of competing with law, the fact-fiction disjunctions that Rushdie highlighted after the fatwa are equally valid. Therefore, the assertion of literature as quasilegal, taken in the strongest possible sense, requires a misunderstanding of law's very different material origins and effects.

If law characteristically reinscribes history for its own ends, then Rushdie's fiction claims quasi-legal status in the same way that J. Hillis Miller suggests Heinrich von Kleist's fiction does: "[T]he reader concerned with the potential lawmaking power of literature is made uneasy .... It is impossible to tell from any markers within the story itself where history stops and fiction begins ...."118 While The Satanic Verses is not patently based on highprofile recent history, like Midnight's Children and Shame, ${ }^{119}$ it does have some contemporary factual allusions, though, as one author writes, "few readers are likely to understand more than a fraction of the references." 120 Moreover, Rushdie himself has emphasized the extent of historical record on the Prophet Muhammad's life, ${ }^{121}$ so that his reimagining of the birth of Islam certainly competes with the official story on which Islam and Islamic law are founded.

116. For examples of other literary works that directly or indirectly resulted in controversy. see NIKOs KazANTZAKIS, THE LAST TEMPTATION OF CHRIST (P.A. Bien trans., 1960); GORE VIDAL. MYRA BRECKINRIDGE (Random House 1986) (1968).

117. Cf. Wesson, supra note 107, at 338, 346.

118. Hillis Miller, supra note 101, at 310.

119. Consider Rushdie's own statement that "'Midnight's Children had history as a scaffolding on which to hang the book; [The Satanic Verses] doesn'L." French, supra nole 34, at 43. reprinted in Thie RUSHDIE FILE, supra note 6, at 6-7.

120. PIPES, supra note 9 , at 54 .

121. Shrabani Basu, Of Satan, Archangels and Prophets. SUNDAY (India), Sept. 18-24, 1988, reprinted in THE RuSHDIE FILE, supra note 6, at 32, 33 (interview with Salman Rushdie) ("He's the only prophet who exists even remotely inside history."). But of. Bandung File: Interview with Salman Rushdie, supro note 11, at 22 ("[O]ne can't really speak with absolute certainty about that period of Mohammed's life. The records are very partial and ambiguous. But he is ... the only prophet who exists even partially in history."). 
Before the fatwa, Rushdie had already abstracted this habit of competing into an aesthetic of turf warfare. Rushdie's literature was to relate to history (and, implicitly, law) as a rival, undertaking to remake history in its own normative image. Because writers and politicians both "try to make the world in their own images," Rushdie wrote in 1982, "they fight for the same territory," and therefore, "literature can, and perhaps must, give the lie to official facts." In his 1984 essay Outside the Whale, Rushdie posited "literature" as a quasi-legal instrument of social construction and change, and in fact, as just that which can decide the historian's dilemma ${ }^{123}$ by providing a superior, more correct story about reality:

The modern world lacks not only hiding places, but certainties. There is no consensus about reality between, for example, the nations of the North and of the South. What President Reagan says is happening in Central America differs so radically from, say, the Sandinista version, that there is almost no common ground. It becomes necessary to take sides .... It seems to me imperative that literature enter such arguments, because what is being disputed is nothing less than what is the case, what is truth and what untruth. If writers leave the business of making pictures of the world to politicians, it will be one of history's great and most abject abdications.

Outside the whale is the ... continual quarrel, the dialectic of history. Outside the whale there is a genuine need for political fiction, for books that draw new and better maps of reality, and make new languages with which we can understand the world. ${ }^{124}$

Nothing succeeds like success. Apparently, literature can make its competing picture of the world more effectively than Rushdie had bargained for. As Edward Said has since suggested, if the above-quoted passage says that writers of fiction cannot be "insulated from history and politics," then it applies to Rushdie's later predicament in an "ominously prophetic," ironic manner. ${ }^{125}$ Outside the Whale, however complex and self-aware it may be, is neither ironically intended nor esoterically coded. Yet it is plainly capable of meaning more than its author can handle. Later incredulous about responses to The

122. SALMAN RUSHDIE, Imaginary Homelands, in IMAGINARY HOMELANDS, supra note 27, at 9, 14.

123. See supra text accompanying note 111 .

124. SALMAN RUSHDIE, Outside the Whale, in IMAGINARY HoMELANDS, supra note 27, at 87, 100; cf. Sohail Inayatullah, Understanding the Postmodern World: Why Khomeini Wants Rushdie Dead, THIRD TEXT, Summer 1990, at 91, 91-93 (1990) (urging that fatwa and The Satanic Verses are similar in that both are ways of responding to modem world); Harold Hongju Koh, Justice Blackmun and the "World Out There", 104 YALE L.J. 23, 25 (1994) ("These searing experiences taught him that Justices have no choice but to take sides .....").

125. Edward W. Said, Statement at Public Meeting (Feb. 22, 1989), in THE Rushdie File, supra note 6 , at 164,164 . 
Satanic Verses, ${ }^{126}$ perhaps Rushdie had not mastered the full import of his own categories before writing; perhaps he had failed to anticipate the kind of material consequences at stake in law, history, and politics.

Such a reading has to be qualified in one obvious way. If Outside the Whale constatively establishes that "literature is like law" (as opposed to "literature is law"), it already implies the further qualification that literature is also not like law-apples are like oranges only because they are also not like oranges, otherwise they would simply be oranges. Moreover, even if Rushdie overstated the case for quasi-legal fiction in Outside the Whale, he was not unaware, even then, of fiction's genuinely fictional objectives. In a 1983 response to disgruntled readers of Midnight's Children, he wrote that they "wanted ... [Midnight's Children] to be the history, even the guidebook, which it was never meant to be ... [and] were judging the book not as a novel, but as some sort of inadequate reference book or encyclopaedia."127 Later, he pressed a similar defense in aid of The Satanic Verses. "I am not trying to say," he wrote in 1990, "that The Satanic Verses is 'only a novel" and thus need not be taken seriously ...."12s But,

to say that ... literature and politics . . . fight for the same territory ... is very different from somehow knowing, in advance, that . . . the conflict your work seeks to explore is about to engulf it . . . and you.

$\cdots$

... Fiction uses facts as a starting-place and then spirals away to explore its real concerns, which are only tangentially historical. Not to see this, to treat fiction as if it were fact, is to make a serious mistake of categories. ${ }^{129}$

That is, political fiction and political action should not be the same for purposes of legal condemnation.

Rushdie had essentially stated, even before the farwa (though in response to already simmering protest), that The Satanic Verses was not about to compete with history and law in the strong sense. In an interview shortly before the fatwa, he said, "The one thing you learn as an historian is just how fragmented and ambiguous and peculiar the historical record is. So I thought,

126. See WEATHERBY, supra note 9, at 150 ('.'I feel completely homified about what happened in Pakistan . . ."” (quoting Rushdie)); The Marked Man: A Writer Driven by Lefe to Dissent. SUNDAY TMSES (London), Feb. 19, 1989, at A17, reprinted in THE RUSHDIE FiLe supra nole 6. at I. 3 ("'If I thought this whirlwind was going to be unleashed, I could not have written."' (quoting Rushdie)): $c$. Basu, supra note 121 , at 32 ("'[I]t would be absurd to think that a book can cause riots."' (quoting Rushdie)). Bur see Bandung File: Interview with Salman Rushdie, supra note 11, at 21 ("I expected that the mullahs wouldn't like it.").

127. SalMAN RUSHDIE, "Errata": Or. Unreliable Narration in Midnight's Children (hereinafter RUSHDIE, Errata], in IMAGINARY HOMEl ANDS, supra note 27, at 22, 25.

128. RUSHDIE, In Good Faith, supra note 27, al 393.

129. Id. at $408-09$. 
well, let's not try and pretend to be writing a history."130 This already qualifies his earlier opinion that literature should enter into arguments about "what is the case." interested in and fantasise them ... so that we don't have to get into the issue: did this really happen like this or did it not?"132

In fact, Rushdie's shifting commitments to politics and imagination are too easily characterized as opportunistic reactions to opposition. The terms of his nonfictional self-defense after the fatwa are indeed more simplistic, binary, and facile than The Satanic Verses itself. ${ }^{133}$ His uncharacteristic fervor about fictionality is clearly defensive, and his implication that fiction and action merit different legal treatment is essentially a justification for liberal free speech protection of a novel that, on its own terms, probably denies the rationalist (if not moral) certainty undergirding arguments for free speech. ${ }^{134}$ Had The Satanic Verses been able to speak to Rushdie after the fatwa, it would have certainly told him to stop making sense. But it is a mistake to see this enforced simplification as Rushdie's compromise, prompted by the incident. If anything, the "compromise" preexisted its own incidental exposure. The author's feeble progression from overstatement of literature's powers to overstatement of its limitations is better understood as a coexisting affinity and gap between law and literature, as an ability in both to compromise and to dominate the other. Rushdie did state literature's abilities too expansively, but literature's legal and political powers, its ability to effect material consequences, compete with and compromise law, are visibly impressive. If Rushdie went on to overstate literature's limitations and different priorities, literature nevertheless does have these limitations, even when it changes people's lives as profoundly as it did in this case.

\section{MULTIPLE VOICES IN LAW AND LITERATURE}

Part III showed that the paraphrasing/misreading/not-reading of literature necessary to achieve legal pronouncement in the Rushdie incident is a special case of, or a parable for, the simultaneous affinity and divergence between law and literature. Since many close readers were no doubt also offended by The

130. Bandung File: Interview with Salman Rushdie, supra note 11, at 22.

131. See supra text accompanying note 124 .

132. Bandung File: Interview with Salman Rushdie, supra note 11, at 22.

133. See S. Nomanul Haq, Salman Rushdie Did Wrong, INT'L Herald TRIB. (Sing.), Feb. 24, 1989, reprinted in THE KISS OF JUDAS, supra note 19, at 35, 35 (using Rushdie's own fictional preoccupation with history against him to argue that he should have been sensitive to cultural context); RICHARD WEBSTER, A BRIEF HISTORY OF BLASPHEMY: LIBERALISM, CENSORSHIP AND "THE SATANIC VERSES" 89 (1990) (chastising Rushdie for rediscovering "naive faith" in expressibility or identifiability of authorial intention in order to prociaim "good faith" intentions); $c f$. RUSHDIE, THE SATANIC VERSES, supra note 1, at 427 ("[T]his sounds, does it not, dangerously like an intentionalist fallacy?").

134. For a discussion of disparities between The Satanic Verses and the free speech arguments later used to justify it, see supra note 56 and accompanying text. 
Satanic Verses, ${ }^{135}$ the law and literature within the Rushdie incident also require another comparison: specifically, a comparison of their relative conceptions and accommodations of authorial intention. As this Part shows, the Rushdie incident contributes to a sharp sense of difference between novelistic literature and fundamentalist legality in terms of their relative conceptions of authorial intention - the former allowing authorial intention to be diluted into and overpowered by contesting voices within the novel; the latter demanding, even imposing ex machina, a fully intending, univocal author ${ }^{136}$ who can be held responsible.

As this Part also shows, certain "pluralist" responses to the fatwa seem to trivialize this law-literature opposition by championing literary multivoicedness as befitting a perfectly pluralist, multicultural legal society. But these arguments reconcile law and literature at three unseen insincerities. First, semaphoring novelistic multivoicedness into legal protection of cultural diversity is playing fast-and-loose; it reappropriates "differences within" a literary work (in the form of contesting voices) to legitimate a legalistic sanctioning of certain "differences between" people. ${ }^{137}$ As such, it also simplifies and censors literary objectives for its own purposes. Second, to the extent that pluralist legal society is not perfectly pluralist and pluralist ideals do not match real conditions, the seeming law-literature marriage can justifiably be said to mask a battle of ideologies (secular vs. fundamentalist), a conflict of laws so to speak. Third, the "law" that even pluralist society relies on might have historical and conceptual attachments to a quasi-religious authoritarianism.

Finally, this Part argues that the putative law-literature opposition forefronted in the Rushdie incident might also be understood as a struggle between competing literary ideologies, since Islamic legal society perceives little difference between the categories of law, religion, and literature. If Islamic religious texts and the legal narratives that derive authority from them are themselves self-consciously literary texts, then the nature of the lawliterature opposition in the Rushdie incident obviously requires rethinking.

\section{A. Traces of "Rushdie" in Rushdie's Novel}

Fiction comes with the disclaimer that it may be unreliable when compared to a Michelin guide. As Rushdie peevishly replied to those who had found historical errors in Midnight's Children, "It is . . obvious, I hope, that Saleem

135. Cf. PIPES, supra note 9, at 113.

136. By "fully intending, univocal author." I mean one who conveys her intent through fictional volces (characters or narrator, for example) that serve largely as mouthpieces for this one intent (hence the word "univocal"). The most elementary example is the lyric poet. if the poetic voice ean be taken as an autobiographical one.

137. See supra text accompanying note 68 . 
Sinai is an unreliable narrator, and that Midnight's Children is far from being an authoritative guide to the history of post-independence India." ${ }^{138}$ Here, denial of authorial culpability turns on the implication that Rushdie himself is not Saleem Sinai, that even if the character shares characteristics with the author, he is not simply a mouthpiece for the author. This argument itself was a large part of Rushdie's self-defense after the fatwa. For even if it is granted that words and passages from The Satanic Verses are blasphemous, ${ }^{139}$ the question remains-whose blasphemy is it? Where Muslims took offense when profanity was attached to revered figures, Rushdie retorted that the words were spoken by characters in the novel and therefore not expressive of authorial viewpoint, ${ }^{140}$ or that they were dreamed by one of the characters and hence mediated by that character's subjectivity. ${ }^{141}$ Of course, a distinctly authorial voice does exist in parts of The Satanic Verses, as in the following cheeky reverie:

Halfway between Allahgod and homosap, ... [angels] did [doubt]: challenging God's will one day they hid muttering beneath the Throne, daring to ask forbidden things: antiquestions. Is it right that. Could it not be argued. Freedom, the old antiquest. He calmed them down, naturally, employing management skills à la god. Flattered them: you will be the instruments of my will . . . . Human beings are tougher nuts....

I know; devil talk. Shaitan interrupting Gibreel. $\mathrm{Me} ?^{142}$

Though this irreverence appears to be coming directly from "Salman Rushdie," however, the "free will" of characters to do and say as they please can apply to the first-person narrator as well. In fact, the passage plays with this very uncertainty, and arouses the reader precisely by inviting her to look who's talking. Even the final doubt about who actually is the responsible devil ("Me?") has doubtful authorial origin. ${ }^{143}$

Many offended close readers (as well as nonreaders) responded to the assertion of authorial distance and dispassion by arguing that it was only a trick to disguise actual blasphemous intent. Indeed, the greater the authorial distance, the greater then seemed the author's craftiness. Often, such readers

138. RUSHDIE, Errata, supra note 127, at 22-23.

139. The novel occasionally provides interpretive alternatives that are not blasphemous. See, e.g., PIPES, supra note 9, at 67 ("This closing incident to Mahound's life can be read in either of two ways, one inimical to Islam, the other not.").

140. RUSHDIE, In Good Faith, supra note 27, at 401 ("[T]he insults quoted are clearly not mine but those hurled at the faithful by the ungodly.").

141. Id. at 399 ("II]t must be remembered that the waking Gibreel is a coarse-mouthed fellow, and it would be surprising if . . . [his] dream-figures . . . did not sometimes speak [like him].").

142. RUSHDIE, THE SATANIC VERSES, supra note 1, at 92-93.

143. This technique of self-conscious, first-person narration is repeated throughout the book, in playful alternation between renunciation and reassumption of trustworthy voice. See, e.g., id. at 10, 133, 408-09. 
used metaphors of hiding - thus Rushdie was accused of hiding blasphemous intent behind "narrative and stylistic tricks" like dream sequences and blaspheming characters. ${ }^{144}$ "You cannot take shelter behind the plea that after all it is a dream sequence in a piece of fiction," wrote Shahabuddin. "[Y]our act is not unintentional . . . . It was deliberate and consciously planned with devilish forethought ...."145 Another response, reminiscent of American Commerce Clause jurisprudence, ${ }^{146}$ was interesting: "Verbal distancing from blasphemy is easier than financial 'distancing'. I assume Salman Rushdie is still collecting royalties . . .."147

\section{B. The Bakhtinian Novel}

This relentless search for authorial intention in narratives that legitimate hostile legal pronouncement against Rushdie suggests that fundamentalist legal proscription is at odds with novelistic literary narrative. The novel, according to the going conception, is the genre in which multiple, competing voices each get their "day in court" before a largely impartial, or at least not immediately positionally identifiable, author. As the narratologist Mikhail Bakhtin has popularly been taken to mean, the novel, unlike the lyric poem, is the genre in which authorial voice can be overtaken by competing, variously untrustworthy voices, while the "negatively capable"148 author suspends sidetaking. ${ }^{149}$ The novel is "dialogic," because voices compete within it through intersubjective dialogue, without any particular subjectivity necessarily privileged as representative of the authorial voice. Not surprisingly, several of Rushdie's defenders (including Rushdie himself) either mentioned Bakhtin or took the Bakhtinian line in situating the novel within the incident. ${ }^{150}$ Of

144. Jussawalla, supra note 41 , at $110-11$.

145. Shahabuddin, supra note 13 , at 39 .

146. Specifically, it resembles the logic of cases enabling broad use of the commeree power. See. e.g. Katzenbach v. McClung, 379 U.S. 294, 305 (1964) (using commerce power for civil rights policing) ("The power of the Congress in this field is broad and sweeping ... . The Civil Rights Act of 1964 . . we find to be plainly appropriate in the resolution of what the Congress found to be a natsonal commercial problem ....").

147. A Testimony, AFr. Events (London), Feb. 1991, at 37. 39 (interview with Ali A. Mazrui), reprinted in SACRILEGE, supra note 40 , at $312,312$.

148. "Negative capability" is a criterion of detachment that English poet John Keats applied to distinguish good authors from bad. Letter from John Keats to George and Thomas Keats (Dec. 21. 1817). in THE LETTERS OF JOHN KEATS 69, 71 (Maurice Buxton Forman ed., 1952); cf. Weisberg. supra note 3, at 16 (discussing use of "negative capability" in work of Roberto Unger).

149. For similar discussion of the novel by Bakhtin, see M.M. BAKHTIN, THE DLALOGIC IMLGINATION 324-25 (Caryl Emerson trans., Michael Holquist ed. \& trans., 1981).

150. Carlos Fuentes, Words Apart, GUARDian (London). Feb. 24, 1989, at 29, reprinted in ThiE RUSHDIE FILE, supra note 6, at 241, 241 ("I have thought a lot about Bakhtin while thinking about Salman Rushdie . . ."); Conference at the Institute of Contemporary Arts in London (Mar. 19. 1989), in THE RUSHDIE FILE, supra note 6, at 179, 182 (comments of Maggie Gee) (anguing that novel form is "inherently blasphemous"); id. at 188 (comments of Malise Ruthven) (agreeing with Maggie Gec); $c f$. Howl $K$. BHABHA, THE LOCATION OF CULTURE 226 (1994) ("It is the medium Rushdie uses to reinterpret the Koran that constitutes the crime."); SALMAN RUSHDIE, is Nothing Sacred?, in IMAGINARY HoMELANDS, supro 
course, the vision of fiction as preferably positionless already compromises Rushdie's earlier argument that fiction should take sides. And, undoubtedly, an author entertaining blasphemous stances within a novel without adopting them can still be foreseeably offensive. In that sense, Rushdie's retreat behind Bakhtinian principles may be a questionable defensive tactic. But on the other hand, even side-taking fiction, by virtue of its literariness, may imply a different kind of authorial intentionality than that with which the law normally concerns itself.

In literary critical terms, the implications of Bakhtinian writerliness for Rushdie's intentionality are legion. Multivoicedness has the obvious sense of multiple characters and voices, with no voice clearly representative of the author. In authors like Rushdie, multivoicedness carries the related sense of ironic double talk (multiple voices within a single speaking voice), where characters and author say or allow to be said the opposite of what they mean, with sarcastic effect-this is what literary critics might call a betrayal of selfmimesis in false repetition, a consistently deadpan or sardonic renunciation of sincerity. More generally, this kind of writerliness implies an ironic tone, which Rushdie's work certainly has. ${ }^{151}$ If ironic double talk and a persistently ironic tone mean that what is stated cannot be trusted to have been sincerely stated, it is also important to recognize that in Rushdie's fiction, just as in many other ironic literary works, disdain for what has been stated does not make it easier to identify authorial position in a determinate "unsaid." Rather, the more fitting model for Rushdie's fiction is Wayne Booth's description of multiple ironies canceling each other out and ending as positionlessly as they started. ${ }^{152}$

\section{Consequences of Bakhtinian Multivoicedness}

The question of Rushdie's intentionality is thus different depending on whether intentionality is at stake for a narrative justifying legal judgment or for a narrative of literary criticism. Bakhtinian multivoicedness is aesthetically pleasing to a literary critic but either nonassimilable or incomprehensible for purposes of fundamentalist legal pronouncement. The hostile response to The Satanic Verses represents a failure to read irony as innocent because expressive of authorial distance. This may be a characteristic of law generally. Early American courts also refused to recognize any ambiguities in ironic posturing,

note 27 , at 415,420 ("[W] always been about the way in which different ... narratives quarrel . ...").

151. See RUTHVEN, supra note 20, at 11 ("Irony? Or something more uncanny? Irony seems too feeble a term to ... [describe] The Satanic Verses . . . ."); see also JAMES HARRISON, SALMAN RUSHDIE 116 (Twayne's English Author Series No. 488, 1992) (categorizing novel as "social satire"); Conference at the Institute of Contemporary Arts in London, supra note 150, at 191 (comments of Marina Warner) (finding novel to be progeny of tradition of "moral satire").

152. WAYNE C. BOOTH, A RHETORIC OF IRONY 62 (1974). 
and generally took satire or sarcasm to present incriminating mens rea for purposes of a blasphemy charge. ${ }^{153}$

Conversely, literary critics could never be prosecutors, and not only for their different ideas about multivoicedness: What the celebrated English professor Walter Jackson Bate said about Samuel Johnson-that interpreting him meant encountering him on the way back, that he had always already discovered the interpretation being given him $^{154}$-may be a compliment coming from Bate, but is surely intended to incriminate when coming from Shahabuddin. ${ }^{155}$

Rushdie's later complaint against such prosecutorial judgment reasserted his underlying writerliness: "He did it on purpose is one of the strangest accusations ever levelled at a writer. Of course I did it on purpose. The question is, and it is what I have tried to answer: what is the 'it' that I did?"156 The Satanic Verses is almost certainly aware of its blasphemous potential, even if when Rushdie "expected that the mullahs wouldn't like it," 157 he probably did not expect a media-effected death sentence. As Sara Suleri writes, "one of the most seductive aspects of The Satanic Verses is the author's acute consciousness of its status as blasphemy."158 Rushdie's qualification ("what is the 'it' that I did") refines this characterization by claiming a use of blasphemy for other ends. ${ }^{159}$

153. Note, Blasphemy, 70 COLUM. L. REV. 694, 705 (1970). See generally LEONARD W. LEVY. BLASPHEMY: VERBAL OFFENSE AGAINST THE SACRED, FROM MOSES TO SAlMAN RUSHDIE (1993).

154. W. JACKSON BATE, SAMUEL JOHNSON 4-5 (1977). The sense that Johnson might be anticipating and defeating the interpreter's expectations is submerged in Bate's assessment, the plain meaning of which is to extol Johnson's breadth of subject matter. Still, one gets the sentiment in Bale that he would not mind being mastered by Johnson in the former, more radical sense.

155. See Shahabuddin, supra note 13, at 39 ("It was deliberate and consciously planned with devilish forethought ....").

156. RUSHDIE, In Good Faith, supra note 27, al 410. For a critique of Rushdie's attempt to answer for the "it," see WEBSTER, supra note 133, at 89. David Berry aleried me to the possibility of reading Rushdie's question as "an honest, un-rhetorical question to which he doesn't know the answer more than [other readers]." Powerful legal and literary texts themselves "speak first, by communicating to the reader his own innermost thought .. . [like] Lincoln's second inaugural address, which astonished some contemporaries by speaking the truth of their collective suffering, the truth they recognized at once but had never heard before." Letter from David Berry. Ph.D. Candidate in English and American Literature. Harvard University, to author (Dec. 4, 1994) (on file with author).

157. Bandung File: Interview with Salman Rushdie, supra note 11 , at 21.

158. Suleri, supra note 56, at 606 .

159. The legitimate kemel in Rushdie's protest must be a proposed distinction between intent to write everything he wrote and what is often called "malicious intent," the kind of intent that the American common law of blasphemy often required for incrimination, to exclude the offender "who fairly and conscientiously promulgates the opinions with whose truth he is impressed." Note, Blasphemy, supra note 153, at 705 (quoting State v. Chandler, 2 Del. (1 Harr.) 553, 564 (1837)); cf. RuSHDIE, In Good Fanth. supra note 27, at 405 ("I do not accept the charge of blasphemy, because, as somebody says in The Salanic Verses, "where there is no belief, there is no blasphemy." "). Whether or not the writing of The Satanic Verses qualifies as something like "wanton disregand" also seems relevant. 


\section{Bakhtinian Dialogism as Liberal Dialogue}

The question is, can literary dialogism have ideological significance for a counternarrative that might be used with legalistic import to defend Rushdie against censorship? As many will agree, the artistic quality of speech should be relatively irrelevant to its enjoyment of legal protection. But some of Rushdie's fellow men and women of letters came close to arguing for the multivoiced novel in terms that evoked the pluralist legal state. E.L. Doctorow, for example, observed that "[t]he writer['s] . . . mind is a democracy of contentious voices, each claiming to be the truth."160

It is a small step from the mind's democracy to the state's democracy, and the multivoicedness or, more generally, "inherent ambiguity" of artistic expression $^{161}$ is easily amenable to pluralist reconstruction of such expression as befitting and welcome in a heterogeneous, perfectly pluralist legal society. Multiculturalism can be a shifting rhetorical value, given that it has been deployed with equal force to show Rushdie as the secular Westerner insensitive to the beliefs of what is a religious minority in England. ${ }^{162}$ But if the Rushdie incident is configured to present the usual censorship issues, ${ }^{163}$ multiculturalism can work in Rushdie's favor. The standard line is that taken by artist Richard Serra in defense of his own censored sculpture (and Serra

160. Doctorow, supra note 58, at 159; see also Fuentes, supra note 150 , at 30 , reprinted in TuE RUSHDIE FILE, supra note 6, at 243 ("Fiction is a harbinger of a multipolar and multicultural world . . . ."); Conference at the Institute of Contemporary Arts in London, supra note 150, at 182 (comments of Maggic Gee) ("[N]ovels have tended to become popular when ... individuals are becoming . . . aware of their own specific identities and beliefs."); $c f$. RuSHDIE, Is Nothing Sacred?, supra note 150, at 420 (pointing to disparities between novelistic multivoicedness and religious univocalism).

161. See Marjorie HeINS, SEX, Sin, and Blasphemy: A Guide to America's Censorship WarS 6-7 (1993) ("All censorship contradicts freedom, but . . . creative expression is inherently ambiguous. . . . To interpret ... [it] literally and reductively is to miss the point.").

162. See, e.g., S. Res. 72, 101 st Cong., 1st Sess., 135 CoNG. REC. S1801 (daily ed. Feb. 28, 1989) (condemning "state-sponsored terrorism" but recognizing "sensitivity of religious beliefs and practices"); Jimmy Carter, Rushdie's Book Is an Insult, N.Y. TIMES, Mar. S, 1989, at E23; cf. Yasmin Alibhaj, Satanic Betrayals: Is There Anyone Here for Multiculturalism?, NEW STATESMAN \& SOC'Y, Feb. 24, 1989, at 12 (discussing both traditionalist and local British pressures leading British Muslims to retain fundamentalist postures). But see LE MONDE (Paris), Feb. 28, 1989, at 3, reprinted in THE RUSHDIE FILE, supra note 6, at 134 (quoting Jean-Marie Le Pen of French National Front in his use of fatwa as warning for ovils of Muslim immigration to Europe).

163. Cf. Against Immoral Threats, L.A. DAILY J., Feb. 22, 1989, at 6 ("[P]rotecting . . . [Rushdie] is to protect artistic expression and intellectual freedom. Those are two hostages that the West cannot allow militant bigotry to seize."); Martin Garbus, Government Should Protect Booksellers, Publishers, N.Y. L.J., Feb. 28, 1989, at 2; David Kirp, When the Koran and the Constitution Clash, L.A. DAILY J., Apr. 12, 1989, at 6; Anthony Lewis, How To Answer the Ayatollah's Threat, L.A. DAILY J., Mar. 14, 1989, at 6; A New Form of Terrorism, L.A. DAlLY J., Mar. 2, 1989, at 6 ("Rushdie . . . has been made an intemational symbol of the value of freedom of expression."); Maxine Sonnenburg, Murder Ex Cathedra, L.A. DAlLY J., Feb. 22, 1989, at 7; Works of Art Need No Apologies, OBSERVER (London), Feb. 19, 1989, at 14, reprinted in THE RUSHDIE FILE, supra note 6, at 98, 98 ("It is not the job of the artist to make life more comfortable for ... governments. It is the job of democratic governments to protect the artist's right to free expression . . . ."). But cf. VLA Perspectives: Lessons from the Rushdie Affair, 13 CoLUM.-VLA J.L. \& ARTS 505, 512 (1989) ("“Certainly a black and white censorship issue, but I certainly didn't think it was a First Amendment issue."' (quoting Bernard Rath)). 
goes on to defend Rushdie as well ${ }^{164}$ ): "The assumption of a universal standard [for obscenity or decency] is presumptuous. There aren't any homogeneous standards in a heterogeneous society. There is no univocal voice. Whose standards are we talking about? Who dictates these standards?"16s The apparent law-literature opposition in the Rushdie incident thus seems a merely contingent one. If only pluralist society could match its own pluralist ideals, the argument is, there would be minimal legal encroachment on freedom of literary expression. There is much to be said in favor of this proposed law-literature union. Where it is actualized, writers and artists do have a greater degree of psychic and expressive freedom in some sense.

The first problem with this defense of Rushdie, to the extent that it sees artistic ambiguity legitimating or repeating societal heterogeneity, is conceptual. Bakhtinian literary dialogue and ambiguous artistic expression only parallel democratic relations between people in a trivial manner, if at all. There is thus no essential reason why they should be especially fitting in a democratic state. ${ }^{166}$ Bakhtinian dialogism is not Bruce Ackerman's "constrained liberal dialogue" 167 -interpreting it as such can mean doing violence to its literary purpose. A certain kind of writerliness cannot be translated without cost into a certain kind of legalism. Authorial intention may be too dissipated in a novel to be retrievable at all. If it is retrievable, the ultimate end of intersubjective dialogue within The Satanic Verses is not to organize rational power relations between liberal subjects, but, arguably, to question liberal assumptions about individualism and free, detached selfhood. ${ }^{168}$ There is no reason to think that this kind of novel is an intellectual mimicry of the multicultural, liberal state, any more than there is reason to think that liberal dialogue borrows from novelistic literary sensibility. Even if pluralist principles guarantee toleration of Rushdie's book, the book itself might be a substantive critique of the basis for liberal selfhood. Carlos Fuentes and others ${ }^{169}$ may defend Rushdie in terms of the novelistic ideal, but pluralist protection of Rushdie does not have much to do with reading literature.

Second, to the degree that pluralism is not actualized in modem pluralist societies, Muslims may be justified in objecting to selective pluralist

164. See Richand Serta, An and Censorship. 17 CRInCAl INQuiry 574. 579 (1991).

165. Id. For other defenses of Rushdie in terms of multiculturalism, see supra note 160.

166. Cf. Letter from Graham Swift, INDEPENDENT (London), Mar. 7. 1989, at 19, reprinted in THE RUSHDIE FilE, supra note 6, at 200, 201 ("A work of literature is more than free expression. It is creauve expression .....). In addition to being a misinterpretation of creative expression, the pluralistic defense of Rushdie is no doubt also a misinterpretation of pluralism.

167. See ACKERMAN, supra note 57, at 4-13 (averring constrained dialogue as guiding pnneiple for liberal dispute resolution and resource allocation).

168. See Slaughter, supra note 14, at 202 ("TThe postmodern like Rushdie dentes the essential unuty of both the [Muslim] and the liberal subject.").

169. See supra note 160 and accompanying text. 
arguments. ${ }^{170}$ In principle, it is not a blow to the pluralist law-literature reconciliation to say that pluralism is often not fully effected in pluralist regimes. ${ }^{171}$ But the realpolitik lapses exposed by the Rushdie incident show significant remnants of univocalism in a legal structure that purports to tolerate multivoiced literature. Most egregiously, the absence of black-letter First Amendment principles in Britain ${ }^{172}$ means that statutes and common law criminalizing blasphemy remain, and more astonishingly, that they continue to offer official protection to the Christian religion only. ${ }^{173}$ By republicizing this inequity, the Rushdie incident drew direct Muslim protest against British blasphemy law, ${ }^{174}$ occasioned a seminar on English blasphemy law organized by the Commission for Racial Equality and the Inter-Faith Network of the United Kingdom, ${ }^{175}$ and incited a spate of new works proposing reform ${ }^{176}$ and even abolition ${ }^{177}$ of English blasphemy law.

Third, as the condition of English blasphemy law intimates, secular regimes, even if they officially relegate religious belief to a private sphere, may be indebted both historically and ideologically to religion. If pluralist regimes are not so deracinated from religion as to be innocent of univocal authoritarianism, some conflict between law and Bakhtinian writerliness is systemic even in pluralist legal society. The history of American blasphemy law shows that secular and religious conceptions of social order have been frequently indistinguishable. ${ }^{178} \mathrm{~A}$ "secular purpose" doctrine allowed early American courts to avoid the First Amendment and uphold blasphemy laws

170. See, e.g., AKHTAR, supra note 20, at 60 (arguing that freedom is not absolute in democratic society); Letter from M. Akbar Ali, DAILY TElEgRAPH (London), Mar. 9, 1989, at 20, reprinted in ThB RUSHDIE FILE, supra note 6, at 199 ("No freedom can be absolute and, in a democratic society, the individual . . must voluntarily restrain his freedom to stay within the universally accepted bounds of civilised conduct."); $c f$. STANLEY FISH, THERE's No SUCH THING AS FREE SPEECH AND IT'S A GOOD THING TOO 125 (1994) (arguing that categorical speech/action distinction in American jurisprudence has hidden less categorical manipulation designed to yield otherwise smart or equitable results). See generally SIMON LEE, THE COST OF FREE SPEECH 73-105 (1990); Aneta B. Shaparis, Speech, Religious Discrimination, and Blasphemy, 83 AM. SOC'Y INT'L L. PROC. 427 (1989) (remarks of Hurst Hannum, Virginia Leary, Ved Nanda, M. Cherif Bassiouni, and W. Michael Reisman).

171. Arguments that liberal procedure is a univocal substantive value and therefore inherently impermissive of multiculturalism and difference will not be attempted in this Note. For critical legal writing critiquing form/substance distinctions in liberal philosophy, see ROBERTO M. UNGER, KNOWLEDOE \& POLITICS $44-45$ (1975).

172. See JoHn SUTHERLAND, OfFENSIVE LiteratURE: DECENSORSHIP IN BRITAIN, 1960-1982, at 13 (1982) (identifying First Amendment to U.S. Constitution as reason for "sharper and clearer" quarrels in United States than in Britain over literary censorship).

173. See Slaughter, supra note 14, at 183-84; see also supra note 24 and accompanying text.

174. See, e.g., AKHTAR, supra note 20, at 118-23.

175. The resulting monograph is LAW, BLASPHEMY AND THE MULTI-FArTH SOCIETY (Comm'n for Racial Equality ed., 1990).

176. See, e.g., Sebastian Poulter, Towards Legislative Reform of the Blasphemy and Racial Hatred Laws, 1991 PUB. L. 371.

177. See, e.g., NiCOLAS WALTER, BLASPHEMY: ANCIENT \& MODERN (1990).

178. When, before the First Amendment, blasphemy represented a "challenge to the ... combined authority of God and the government," it could constitute a capital offense. See WILLIAM NOBLB, BOOKBANNING IN AMERICA: WHO BANS BOOKS?-AND WHY 196 (1990). 
when they were found necessary to preserve the neutral secular order. ${ }^{179}$ While this doctrine no doubt enabled politically popular decisions, it also evinced some actual inability to divorce legal order from religious authoritarianism. One case made a telling connection between blasphemy law and "secular" public oath taking. ${ }^{180}$ Later, blasphemy statutes were applied to cases of garden-variety swearing where obscenity/profanity prosecution would have been more congenial. ${ }^{181}$ As Harold Berman has written, law shares with religion the need to ritualistically dramatize social values "to induce an emotional belief in them as a part of the ultimate meaning of life."182

Formalistically, a certain piety can continue to color the way in which law understands authorship and intentionality. Just as earlier American courts often failed to read ironic double talk as innocent because expressive of authorial distance, ${ }^{183}$ current copyright doctrine, in its liberal but uncomfortable approach to parody, shows what George Marcus calls a "reverent conception of authorship that treats it as a timeless and natural category of social identity."184 Reverence for authorship also means that authorship stands above community-it cannot be diluted by Bakhtinian interaction with other voices. Thus, Richard Serra precedes his plea for the appropriateness of ambiguous artistic expression within a heterogeneous society ${ }^{185}$ with a criticism of the Yates Amendment (denying federal money to obscene art) ${ }^{186}$ for espousing the very heterogeneous standards he goes on to applaud. Indeed, this plea for homogeneously applicable (and not multiculturally sensitive) legal rules is the basis for his defense of Rushdie: "[In the Yates Amendment] [t]he decision about whether something is obscene is to be made by a local jury, applying community standards. Does this mean that the material in question can be tolerated by one community and another community will criminalize its author? What about Salman Rushdie?"187

179. Note, Blasphemy, supra note 153 , at 702-06.

180. Id. (citing People v. Ruggles, 8 Johns. 225, 230 (N.Y. 1811)). "Secular blasphemy" requires more extended attention than is possible in this Note. Blasphemy is "secular" not just in the sense that promunent blasphemy prosecutions often have historical/political explanations that eclipse religious explanalion. See Conference at the Institute of Contemporary Arts in London, supra note 150, at 186 (anonymous comments). It may also be secular in the sense implicit in the deconstructionist polemic that speech. whether "liberal," "totalitarian," or "religious," is hurful to its own presumed logos. Cf. Gayain Chakravorty Spivak, Reading The Satanic Verses. 2 PUB. Culture 79, 82 (1989) ("The questuon is not if the book is blasphemous.").

181. Note, Blasphemy, supra note 153, at 695, 719. See generally LEVY, supra note 153, at 527-30.

182. HAROLd J. Berman, THE INTERACTION OF LAW ANd ReligioN 32-33 (1974).

183. See supra text accompanying note 153 .

184. George E. Marcus, The Debate over Parody in Copynght Low: An Experment in Cultural Critique, 1 YALE J.L. \& HuMAN. 295, 296 (1989).

185. See supra note 164 and accompanying text.

186. 135 CONG. REC. H6407 (daily ed. Oct. 2, 1989) (enacted in Department of the Intenor and Related Agencies Appropriations Act of 1990. Pub. L. No. 101-121. $\S 304$ (a), 103 Stat. 701. 741 (1989) (to be codified at 20 U.S.C. \$ 954)).

187. Serra, supra note 164 , at 579 . For other, occasionally reluetant, liberal defenses of Rushdie based on appeal to a univocal moral order, see JEREMY WALDRON, Rushdie and Religion. in LIBERAL. RIGirts: 
Pluralist protection of literature does not correct the disparities between legal and literary understanding of authorship that the Rushdie incident exposes elsewhere. In the Rushdie incident, pluralist protection of literature even demands some evasion of actual reading, since the literature being protected, if taken too seriously, probably threatens to overtake pluralist ideology. ${ }^{188}$ Such literature must be dominated if it is to be protected. The moral of the story, therefore, is that when a story is protected instead of punished, the meaning of that story may necessarily have gone equally unheeded. ${ }^{189}$

For Muslim sensibility, on the other hand, the Rushdie incident may not stand for any necessary opposition between law and literature. The Qur'an itself, as the basis for Islamic law, seems to have both literary and legal status. Akhtar writes: "The Rushdie affair has proved that, to Muslims, books matter and that there is a book around [the Qur'an] that can still move mountains.... [O]ne is afraid of the fellow who writes one book in a lifetime, not the one who writes one every year." ${ }^{190}$ This unfaltering equation of legal authority with literature entices an easy analogy with Robert Ferguson's description of the early American Republic, where law and culture were unified in purpose, poetic talent was directed toward inculcation of cultural values, and lawyers were unabashed agents of the state and its distinctively literary word. ${ }^{191}$ It also shows that a law-literature convergence may not be liberating. An excessive alliance of literature with lawmaking, as Brook Thomas points out, can easily "raise the specter of censorship."192 Robert Weisberg also observes that modern pluralist democracy would not tolerate, in either artists or statesmen, the moral authority that Ferguson's vision of the lawyer/lawmaker entails. ${ }^{193} \mathrm{~A}$ "fight for the same territory"194 may indeed be better than a truce. The Rushdie incident even seems to show that the fight is as inevitable as the truce. In Qur'anic law, the legal and the literary have nonetheless been occupying the same territory all along.

COLLECTED PAPERS 1981-1991, at 134, 135-36 (1993) ("This is the place where . . [liberals] have to abandon . . relativism . . . .); Austin Sarat \& Roger Berkowitz, Disorderly Differences: Recognition, Accommodation, and American Law, 6 YALE J.L. \& HUMAN. 285, 315 n.142 (1994) ("It is unlikely that ... the vast majority of Westem individuals are willing to accept the justness of the fatwa; yet to reject it requires an assertion of our authority to judge Islamic law."); Arthur Schlesinger, jr., Multiculturalism and the Bill of Rights, 46 ME. L. REv. 191, 208 (1994) ("Does the fact that The Satanic Verses hurts the feelings of devout Muslims really justify the murder of Salman Rushdie? Let us not forget Bernard Shaw's reminder: “All great truths begin as blasphemies."'); $c f$. ANDREW ALTMAN, CRITICAL LEGAL STUdIES: A LIBERAL CRITQUE 68-69 (1990) (arguing that liberal philosophy does not threaten objective value).

188. See supra note 168 and accompanying text.

189. Cf. Spivak, supra note 180 , at 82 ("What is the distinction between punishment and nourishment [of blasphemy]?").

190. Shabbir Akhtar, Back into the Fold?, AFR. EVENTS (London), Feb. 1991, at 36, 37, reprinted in SACRILEGE, supra note 40, at 309, 311-12.

191. ROBERT A. FERGUSON, LAW AND LETTERS IN AMERICAN CULTURE 25-33 (1984); see also Weisberg, supra note 3, at 9 (discussing Ferguson).

192. Thomas, supra note 100 , at 516-17.

193. Weisberg, supra note 3 , at 12.

194. RUSHDIE, Imaginary Homelands, supra note 122, at 14. 
"Occupation" in the hostile sense, ${ }^{195}$ however, is precisely what is otherwise distressing about the Rushdie incident, for in it, law and literature seem to have transgressed jurisdictional boundaries to effect unholy seizures of foreign territory. A comfortable integration of the two categories cannot nullify the apparent discomfort each causes the other when demarcating its own proper province. Exactly where the Rushdie incident leaves law, literature, or "law and literature" thus remains oddly elusive. ${ }^{196}$

195. But $c f$. Eyal Benvenist,. The INTERNATIONAL LAW of OCCUPATION 3 (1993) ("The law of occupation developed as part of the law of war. Initially, occupation . . was referred to ... as belligerent occupation.' But the history of the twentieth century has shown that occupation is not necessanly the outcome of actual fighting ... and it ... could be the product of a peace agreement.").

196. "For many people," said Rushdie a few years after the fansa. "I ve ceased to be a human being. I've become an issue, a bother, an 'affair."' Rushdic. One Thousand Days in a Balloon, supra note 64. at 16. As an exposition of the Rushdie incident in terms of law and literature, this Note itself nsks becoming another inconsequential abstraction. Yet, what prompted it was the humanity of all who were hur in the Rushdie incident, including Rushdie himself. Interpretation, whether literary or legal, usually has an agenda. and this Note is no different. Relevant normative preferences had best be acknowledged as such, though anything stated comes with an inevitably richer body of the unstaled.

I am and have been a "Rushdie fan." I cannot dismiss the Mustim reaction. though I do not know whether I would not have dismissed it without the catalytic fanva. Some of the reactions strike me as expressions of genuine pain. It is not for me. just as it is not for Rushdie, to presenbe how people should make it possible for themselves to live; I do not feel qualified in the lenst to make that prescription. Nevertheless, my agenda, as far as I know, was to make visible again a reading expenence that, for me. felt far from malicious or hurtul-of course. I stand open to correction. There is a sharpness in Rushdie that can offend, but people do preoceupy him, and when he writes about them. this reader al least has seldom felt the absence of something very close to tenderness. Perhaps that means he lets people off too easily.

As an explanatory genre, tragedy no longer comes without internal difficulues. whether one participates in the tragic design as authorial puppetecr or ignorant puppet. The Satanic Verses is a tragedy that struggles to emerge, that self-consciously confines its tragic moments, makes fun of them. cuts them to pieces. It is hard to say after finishing the book that tragedy. however momentarily luminous, has won over irony. But there is still as much love in the book as there is hate. This is what makes it difficult for me to forget the Rushdie incident. 
